\title{
Opoka-Sediment Rock as New Type of Hybrid Mineral Filler for Polymer Composites
}

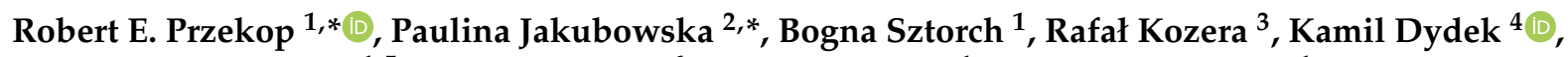 \\ Marek Jałbrzykowski 1,5, Tomasz Osiecki ${ }^{6}$, Piotr Marciniak ${ }^{1}$, Agnieszka Martyła ${ }^{1}$, Arkadiusz Kloziński ${ }^{2}$ \\ and Dariusz Brząkalski ${ }^{7}$
}

check for updates

Citation: Przekop, R.E.; Jakubowska, P.; Sztorch, B.; Kozera, R.; Dydek, K.; Jałbrzykowski, M.; Osiecki, T.;

Marciniak, P.; Martyła, A.; Kloziński, A.; et al. Opoka-Sediment Rock as New Type of Hybrid Mineral Filler for Polymer Composites.

AppliedChem 2021, 1, 90-110. https:// doi.org/10.3390/appliedchem1020008

Academic Editor: Andrea Atrei

Received: 8 September 2021

Accepted: 27 October 2021

Published: 3 November 2021

Publisher's Note: MDPI stays neutral with regard to jurisdictional claims in published maps and institutional affiliations.

Copyright: (c) 2021 by the authors. Licensee MDPI, Basel, Switzerland. This article is an open access article distributed under the terms and conditions of the Creative Commons Attribution (CC BY) license (https:/ / creativecommons.org/licenses/by/ $4.0 /)$.
1 Centre for Advanced Technologies, Adam Mickiewicz University in Poznań, Uniwersytetu Poznańskiego 10, 61-614 Poznan, Poland; bogna.sztorch@amu.edu.pl (B.S.); m.jalbrzykowski@pb.edu.pl (M.J.); piomar12@amu.edu.pl (P.M.); agnieszka.martyla@amu.edu.pl (A.M.)

2 Institute of Chemical Technology and Engineering, Faculty of Chemical Technology, Poznan University of Technology, Berdychowo 4, 60-965 Poznan, Poland; arkadiusz.klozinski@put.poznan.pl

3 Technology Partners Foundation, Pawinskiego 5A, 02-106 Warsaw, Poland; rafal.kozera@technology.partners.pl

4 Faculty of Materials Science and Engineering, Warsaw University of Technology, ul. Wołoska 141, 02-507 Warsaw, Poland; kamil.dydek@pw.edu.pl

5 Faculty of Mechanical Engineering, Bialystok University of Technology, Wiejska 45C, 15-351 Białystok, Poland

6 Department of Mechanical Engineering, Technische Universität Chemnitz, Straße der Nationen 62, 09111 Chemnitz, Germany; tomasz.osiecki@mb.tu-chemnitz.de

7 Faculty of Chemistry, Adam Mickiewicz University in Poznań, Uniwersytetu Poznańskiego 8, 61-614 Poznań, Poland; dariusz.brzakalski@amu.edu.pl

* Correspondence: r.przekop@gmail.com or rprzekop@amu.edu.pl (R.E.P.); paulina.jakubowska@put.poznan.pl (P.J.)

Abstract: The work presents a comprehensive profile of the physicochemical characteristics of opoka sedimentary rock in the context of its use as a hybrid filler for thermoplastics. Determining the functional parameters of the studied filler was the main aim of this research. Thermal treatment leads to changes in its morphology and phase composition. A wide range of physicochemical techniques was used, such as low-temperature nitrogen adsorption, FT-IR, TGA, XRD, optical, and electron microscopy. The susceptibility of the material to micronisation was also tested (ball milling). Due to its widespread occurrence, opoka can be an attractive alternative to fillers such as silica or chalk. In order to verify this statement, polypropylene composites thereof were prepared by melt blending and injection molding, and studied by mechanical testing and microscopic imaging.

Keywords: opoka rock; sediment rock; calcite; $\mathrm{SiO}_{2}$; composite; $\mathrm{CaCO}_{3}$; mineral filler; structural heterogeneity; quartz; thermal treatment

\section{Introduction}

Inorganic mineral fillers can be divided into two groups: natural and synthetic ones (Figure 1). Natural fillers include kaolin, chalk, mica, talc, and sedimentary $\mathrm{CaCO}_{3}$; synthetic fillers include titanium dioxide, silicon dioxide, precipitated aluminium silicate, precipitated calcium carbonate, and gypsum [1].

Mineral fillers are successfully used as modifiers of polymer materials properties, more and more often being a good alternative to synthetic fibers such as: carbon fibers [2], aramide or nylon fibers [3], or glass fibers [4]. They not only reduce the cost of the final product, but also improve parameters such as: mechanical strength [5], thermal stability and flame resistance [6], as well as dielectric properties. Their addition also affects the processing of the polymer [7]. The filler can be introduced into the polymer by various methods including melt-mixing [8], melt extrusion [9], and injection molding [10]. Mineral fillers for thermoplastics often include natural sedimentary rocks, like calcium carbonate [11], mica, clinoptilolite [12], zeolites [13], kaolin [14], silica [15], titanium dioxide [16] 
or diatomaceous earth [17], and clay minerals with a two-layer structure (kaolin-serpentine group) or three-layer structure (talc-pyrophyllite group, mica group, etc.) [18]. Mineral fillers can be used directly or after surface treatment, depending on the polar nature of the polymer [19].

\begin{tabular}{|c|c|c|}
\hline \multicolumn{1}{|c|}{ SYNTHETIC FILLERS } & \multicolumn{1}{|c|}{ MINERAL FILLERS } & FORMULA \\
\hline Precipitated calcium carbonate & Ground limestone & $\mathrm{CaCO}_{3}$ \\
\hline Precipitated aluminium silicate & Clay (hydrated kaolinite) & $\mathrm{Al}_{2} \mathrm{O}_{3} \cdot 2 \mathrm{SiO}_{2} \cdot 2 \mathrm{H}_{2} \mathrm{O}$ \\
\hline Titanium dioxide (rutile, anatase) & & $\mathrm{TiO}_{2}$ \\
\hline Precipitated silica and fumed silica & Quartz & $\mathrm{SiO}_{2}$ \\
\hline Precipitated barium sulphate & Barite powder & $\mathrm{BaSO}_{4}$ \\
\hline & Talc & $3 \mathrm{MgO} \cdot 4 \mathrm{SiO}_{2} \cdot \mathrm{H}_{2} \mathrm{O}$ \\
\hline & Opoka & $\mathrm{CaCO}_{3} \cdot \mathrm{SiO}_{2}$ \\
\hline
\end{tabular}

Figure 1. Examples of some inorganic fillers applied in polymer composites production, including opoka.

Both fillers for composites of natural origin such as limestone, chalk, dolomite, quartz, silicates, a aluminosilicates (including zeolites), etc., and man-made synthetic fillers, either precipitated or obtained in other way, are inhomogeneous group. The variety of their parameters span from density, hardness, grain size, and shape to internal structure (porosity), crystallinity, surface area, moisture (water) content, and hydrophobicity. The structure of these fillers in general is not quite compatible to polyolefin matrix. Surface modification or additional treatment (milling, grinding, chemical treatment or surface modification, calcination) is often required to produce appropriate properties enabling effective dispersion in polymer and miscibility. Natural fillers of the same type but different origin show diversity of composition, presence of absence of additional ions, or intrusive phases.

There are numerous properties of the fillers or their combinations to be considered when applying them to the polymer composite, and the composite's target key properties and function should be an indication to choose suitable material.

Fillers can influence appearance, electrical, and mechanical properties, like impact resistance and tensile strength, wear, and fatigue resistance. Some of them can be directly translated into polymer composite properties, while some can not.

The bulk and specific density of the filler affects the weight of the composite. Fibrous structure of the filler can increase its mechanical strength and increased surface hydrophobicity can lead to rise in miscibility with the polymer matrix. Bulky and lightweight fillers with voids can help decrease the composite density.

As an example, silicas are available in many types, depending on the production or modification method, covering a wide range of parameters.

According to Xantos [19], parameters of functional fillers for polymers of significance with regard to their performance include geometry of the filler, surface area and porosity, chemical, mechanical, physical, thermal, and optical properties pertaining to filler itself. The interactions with the phase boundaries determine adhesion and stress transfer from the matrix the filler. Lastly, the incorporating method of the filler and its final distribution will be also of significance. Controlling of these aspects will impact the properties of the polymer composite and the product itself.

Particle size and shape of the filler particles are the most important factors affecting the properties of composite materials. Insolubility in polymer and chemical inertness of the filler is a prerequisite for its usability. Generally, high purity of filler is not obligatory; however, some impurities are undesirable and can be troublesome at any level as they pro- 
duce adverse effects, e.g., traces of copper, nickel, and iron worsen heat and light stability. Even chemical composition of the filler may have little effect on the composite properties. Most mineral fillers are thermally stable above the polymer processing temperature. Traces of asbestos or crystalline silica may imply health hazards [20]. Particulate fillers usually have considerably higher density than polymers. That is usually an unwanted feature. Excessive hardness of the filler may have a negative effect on the polymer due to increased abrasiveness.

In this work, the use of sedimentary rock (opoka) as a filler of natural origin for thermoplastic composites preparation is proposed.

Opoka is a sedimentary rock, which is a transitional form between carbonate and siliceous rocks, formed in the Upper Cretaceous period as a result of the decalcification of primary rocks [21]. It consists mainly of calcium carbonate (depending on the period of deposit formation 25-48\%) and silica (5-62\%) [20]. Opoka rock may also contain compounds (mainly oxides and salts) of magnesium, aluminium, iron, potassium, sodium, phosphorus, manganese, and titanium. Depending on their content, the material may appear from light gray to creamy white in colour [22] Depending on the Ca/Si ratio in the opoka, it can be divided into light and heavy grades. The light, decalcified grade is characterized by the dominant share of silica in the composition of the rock, while with the predominant amount of calcium, we speak of the heavy grade, the so-called calcareous opoka [21]. In the past, the rock was used in road and building construction, ceramics, in cement, and in chemical industries, mainly due to its good mechanical properties and high thermal resistance [23], and also due to its good sorption properties in water and sewage processes in order to remove phosphorus, magnesium, and iron [24]. Currently, the widespread use of the rock as a high-performance filler for composites requires its comprehensive characterization.

Due to the natural origin of the raw material, the chemical composition (up to several percent) and morphology vary. Rocks from the vicinity of Kraśnik were used in the discussed work. Mineral resources from the Lublin region are mainly limestones, rocks, and sandstones of Upper Cretaceous or Neogene origin [25]. According to the literature data, their characteristic feature is a large proportion of silica in the composition, even above $50 \%$. In the case of the tested samples, the $\mathrm{SiO}_{2}$ content was lower, which translates directly into physicochemical properties. This study presents a comprehensive physicochemical characteristics of the carbonate-silicate opoka rock and its influence on the mechanical properties of PP composites.

\section{Materials and Methods}

The mineral was obtained in Kraśnik in the Lublin Upland and used as the research material. In this area, the material appears as a heavy rock species and forms layers or needles [26]. Heavy opoka grade was used for the studies. The composition of the raw material after calcination at $1000{ }^{\circ} \mathrm{C}$ declared by the manufacturer contents $\mathrm{CaO}(43.33 \%)$, $\mathrm{SiO}_{2}(36.05 \%)$ as the mains compounds with $\mathrm{Al}_{2} \mathrm{O}_{3}, \mathrm{TiO}_{2}, \mathrm{MgO}$, and $\mathrm{MnO}$ addition. ( $3 \%$ in total).

The grinding of the material was performed with a rotary ball mill. Milling jars of $6 \mathrm{~L}$ capacity and ceramic balls of $20 \mathrm{~mm}$ diameter were used. A milling jar was charged with $500 \mathrm{~g}$ samples of opoka and $2 \mathrm{~kg}$ of milling balls, at $10 \mathrm{rpm}$. Every hour, $10 \mathrm{~g}$ sample was taken for an analysis of grain size distribution. The material after grinding $(72 \mathrm{~h})$ was sieved through a vibrating screen of a mesh size of $40 \mu \mathrm{m}$ to eliminate the particle fraction above this size. The sieved material was then used as a filler to prepare polypropylene composites

The samples used in this work were characterized using the following techniques.

\subsection{Particle Size Distribution}

The size of the opoka rock after grinding was measured with Master-sizer 3000 (Malvern Instruments Ltd., Malvern, UK). The measurements were made for the samples in water suspension (Hydro EV attachment). The parameters of measurements for wet samples were stirrer revolution speed $2330 \mathrm{RPM}$, and ultrasound power $70 \%$. 


\section{2. $p H$ Measurements}

Samples of $2 \mathrm{~g}$ of $0.4-0.9 \mathrm{~mm}$ fraction milled and sieved opoka rock samples were taken-including raw material and the samples after heating at $300-1000{ }^{\circ} \mathrm{C}$ in a muffle furnace-and placed in plastic bottles. Two samples were prepared from each material grade, to obtain two series of samples. Next, to each bottle was added:

- $\quad 25 \mathrm{~mL}$ of distilled water for the first series

- $\quad 25 \mathrm{~mL}$ of $1 \mathrm{M} \mathrm{KCl}$ for the second series.

The bottles were capped and shaken on an automatic shaker for $30 \mathrm{~min}$, after which each bottle was opened and the $\mathrm{pH}$ was measured with a $\mathrm{pH}$ meter (Seven Multi SM, Mettler Toledo). After each measurement, the electrode was rinsed with distilled water. $\mathrm{KCl}$ measurements were run to assess the opoka acidity under ion exchange conditions [27].

\subsection{X-ray Diffraction Analysis}

The X-ray powder diffraction (XRPD) measurements were carried out using an Xpert 3 Pro diffractometer (Poznan, Poland) working in the $\theta-2 \theta$ geometry with Ni-filtered $\mathrm{CuK}_{\alpha}$ radiation. The following measurement conditions were applied: $2 \theta 10-100^{\circ}$, scan step $0.010^{\circ}$ at $1^{\circ}$ per minute. The data were directly derived from the XRPD measurements, recalculated in a spreadsheet using the scattering vector formula and presented in a graph.

\subsection{Digital Light Microscopy}

Surface structure and breakthroughs were analyzed under Digital Light Microscope Keyence VHX 7000 with $100 \times$ to $1000 \times$ VH-Z100T lens (Osaka, Japan). All of the pictures were recorded with a VHX 7020 camera.

\subsection{SEM and SEM-EDS (Energy Dispersive Spectroscopy) Analysis}

The surface morphology of the opoka was depicted by a scanning electron microscope (QUANTA 250 FEG Scanning Electron Microscope (Poznan, Poland)) which was operated in high vacuum conditions at a $5 \mathrm{kV}$ acceleration voltage. The energy dispersive spectroscopy (EDS) analyses were conducted at a beam acceleration voltage of $15 \mathrm{kV}$ using an EDAX Octane SDD detector. EDS maps of elements overlay were made with a resolution of $0.3 \mu \mathrm{m}$.

\subsection{Porous Structure}

The porous structure was determined by the low temperature nitrogen adsorption measurements carried out on an Autosorb iQ Station 2 (Quantachrome Instruments (Poznan, Poland)) in standard analysis mode, using 200-300 mg of material with the grain size fraction between 0.1 and $0.2 \mathrm{~mm}$. Prior to the nitrogen adsorption all samples were outgassed for about $10 \mathrm{~h}$ at $350{ }^{\circ} \mathrm{C}$ at $0.4 \mathrm{~Pa}$ until a constant weight was achieved. Both adsorptive and desorptive branches of the isotherm were taken in the range of $\mathrm{p} / \mathrm{p}_{0} 0-1$. Reports were provided by Quantachrome ASiQwin software (version 2.0). The distribution of pore area and pore volume was calculated using the de Boer $\mathrm{t}$-method and the $\mathrm{BJH}$ method. The pore volume and pore diameter were taken from the adsorptive branch of the isotherm using the BJH method. The surface area was calculated using the multi-point BET linear regression method using the $\mathrm{p} / \mathrm{p}_{0} 0.1-0.3$ window and the seven degrees of freedom available (nine data points).

\subsection{FTIR Measurements}

The FTIR measurements were carried out using a Thermo Scientific Nicolet iS50 FTIR spectrometer (Poznan, Poland) in transmission mode. $4 \mathrm{mg}$ samples were ground in an agate mortar together with $200 \mathrm{mg} \mathrm{KBr}$ and pressed at 10 tons pressed into the form of discs. The spectra were recorded using eight scans of background and 16 scans of sample measurements in the $4000-400 \mathrm{~cm}^{-1}$ using a DTGS detector and a $\mathrm{KBr}$ beamsplitter at $0.5 \mathrm{~nm}$ resolution. 


\subsection{Thermogravimetry}

Thermogravimetry was performed using NETZSCH 209 F1 Libra gravimetric analyser. Samples of $5.0 \pm 0.2 \mathrm{mg}$ were cut from each granulate and placed in $\mathrm{Al}_{2} \mathrm{O}_{3}$ crucibles. Measurements were performed under nitrogen and air in a $30-1000{ }^{\circ} \mathrm{C}$ temperature range and at $20^{\circ} \mathrm{C} / \mathrm{min}$ temperature rise.

\subsection{Mechanical Properties}

Mechanical properties were assessed by running tensile tests (traverse speed $100 \mathrm{~mm} / \mathrm{min}$ ) and three-point bending tests (traverse speed $6 \mathrm{~mm} / \mathrm{min}$ until reaching the deflection at maximum load) were determined using the universal testing machine ZwickRoell Z020TH ALL round Line, according to the norm PN-EN ISO 527-2. Shore hardness in D scale was measured with ZwickRoell durometer, according to the norm PN-ISO 868:2005. In the research, samples of neat polypropylene (PP) were used as reference. Composites containing $5 \mathrm{wt} \%$ of different fillers were measured, including calcium carbonate (C5), Aerosil 200 silica (A5), and opoka calcined at different temperatures (O5_800 for $800{ }^{\circ} \mathrm{C}$, O5_1000 for $\left.1000{ }^{\circ} \mathrm{C}\right)$. Calcium carbonate and silica were used for comparison as welldefined and widely used fillers.

\subsection{Preparation of Composites}

Isotactic polypropylene (PP) Moplen HP456J (Basell Orlen Polyolefins, Płock, Poland) with a density of $0.900 \pm 0.003 \mathrm{~g} / \mathrm{cm}^{3}$ and a melt flow index MFI $(230 ; 2.16)=3.09 \pm 0.04$ $\mathrm{g} / 10 \mathrm{~min}$ was used as the matrix of the composites. The fillers used in the tests were: calcium carbonate $\left(\mathrm{CaCO}_{3}\right)$ Omyacarb 2-VA (Omya Sp. z o.o., Warsaw, Poland) with an average grain size (d50) of $3.86 \mu \mathrm{m}$, silica $\left(\mathrm{SiO}_{2}\right)$ Aerosil 200 (Evonik Industries AG, Essen, Germany), of d50 $=12 \mathrm{~nm}$, and raw opoka rock and opoka calcined at $800{ }^{\circ} \mathrm{C}$ and $1000{ }^{\circ} \mathrm{C}$, of $\mathrm{d} 50=28.6 \mu \mathrm{m}$ (fraction $<40 \mu \mathrm{m}$ ).

The polypropylene composites were produced in a two-step process. In the first stage, polypropylene was rolled together with a given filler on a two-roll mill (Zamak Mercator, Skawina, Poland). PP concentrates with $50 \mathrm{wt} \%$ of fillers were obtained, and subsequently diluted to a concentration of $5 \mathrm{wt} \%$ in the process of extrusion with cold granulation. For this purpose, a Zamak Mercator twin-screw extruder with a screw diameter of $d=16 \mathrm{~mm}$ and the ratio L/D ratio of 40 was used. Samples for testing mechanical properties were obtained in the injection molding process using a hydraulic injection molding machine (Battenfeld, model PLUS 35/75 equipped with a two-socket mold) to obtain standardized testing dumbbells in accordance with PN-EN ISO 527-2 (type 1A).

\section{Results and Discussion}

Opoka rock from the Lublin region is off-white, with a slightly cream colour (Figure 1).

Rock surface analysis in 3D using the Keyence digital optical microscope confirms the highly porous and heterogeneous nature of the studied material. The pores take different shapes, from oval to irregular, but do not constitute interconnected networks. Photo shows different mineral particles (Figure 2). The material between consists of fine-grained calcite and silica [28]. 


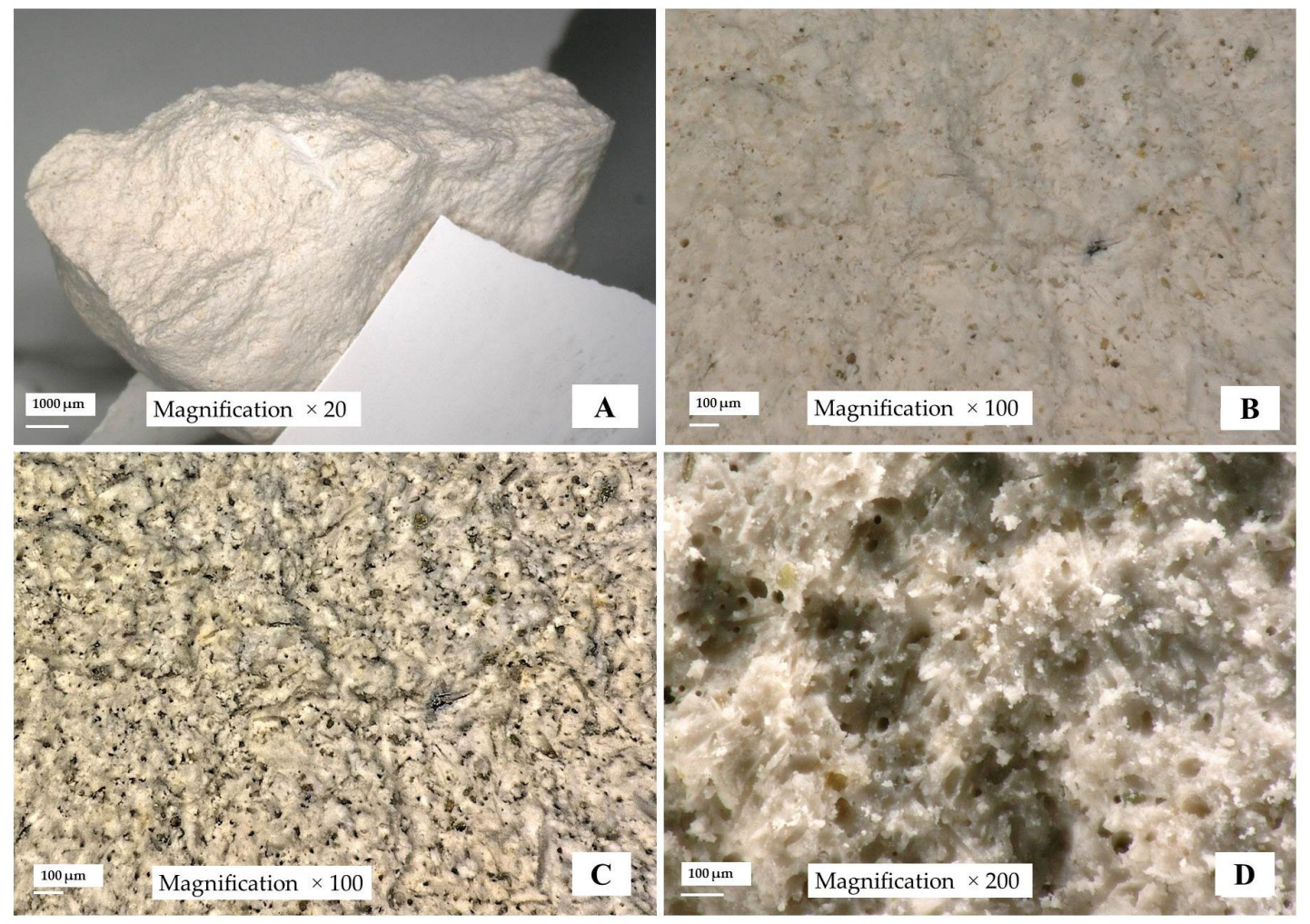

Figure 2. Opoka rock macrostructure: magnification $\times 20$ (A), digital optical microscope imaging: magnification $\times 100$ $($ B,C), magnification $\times 200($ D) .

SEM micrographs show the crystal morphology with monocrystalline dominance [29] (Figures 3 and 4). Most of the calcite is very fine-grained, but some crystals have also been observed. Magnification $(20 \mu \mathrm{m})$ allowed for observation of the porosity of the rock, and at high magnification (Figure 3) on SEM, calcite crystals are clearly visible in the material after processing at a temperature of $300^{\circ} \mathrm{C}$ [28]. A flake structure is visible, which changes after annealing at $1000{ }^{\circ} \mathrm{C}$-fusing of particles into granular form and deformation of plate structures to those with thickened, rounded edges were observedFigure 4G,H. SEM analysis also showed that opoka is rich in Radiolaria and Foraminifera (Figure 3). The microstructure and its hierarchy will have a significant impact on both the mechanical processing of the filler and its subsequent dispersion in the polymer matrix. Ultimately, the properties of the opoka-filled composite will depend on the external and internal microstructure of the filler. Microscopic examination of the unprocessed (raw), and subsequentially mechanically processed and thermally treated material allowed to describe changes in the microstructure. Significant phase and structural transformations were observed in the temperature range of $800-900{ }^{\circ} \mathrm{C}$. It is associated with the decomposition of carbonate phases and the formation of calcium oxide. This causes changes in both the carbonate-rich phases and the formation of new mixed phases between $\mathrm{CaO}$ and $\mathrm{SiO}_{2}$. Opoka is a mixed sedimentary rock, therefore mineralized biological structures constitute a significant part of the material studied. We also observe a number of minerals that have undergone transformation or crystallization. A significant part of the material is crystalline, which is visible on the diffraction patterns (XRD). The observed complexity and structural heterogeneity may be a significant advantage of this raw material over synthetic fillers, such as precipitated chalk or $\mathrm{SiO}_{2}$. 

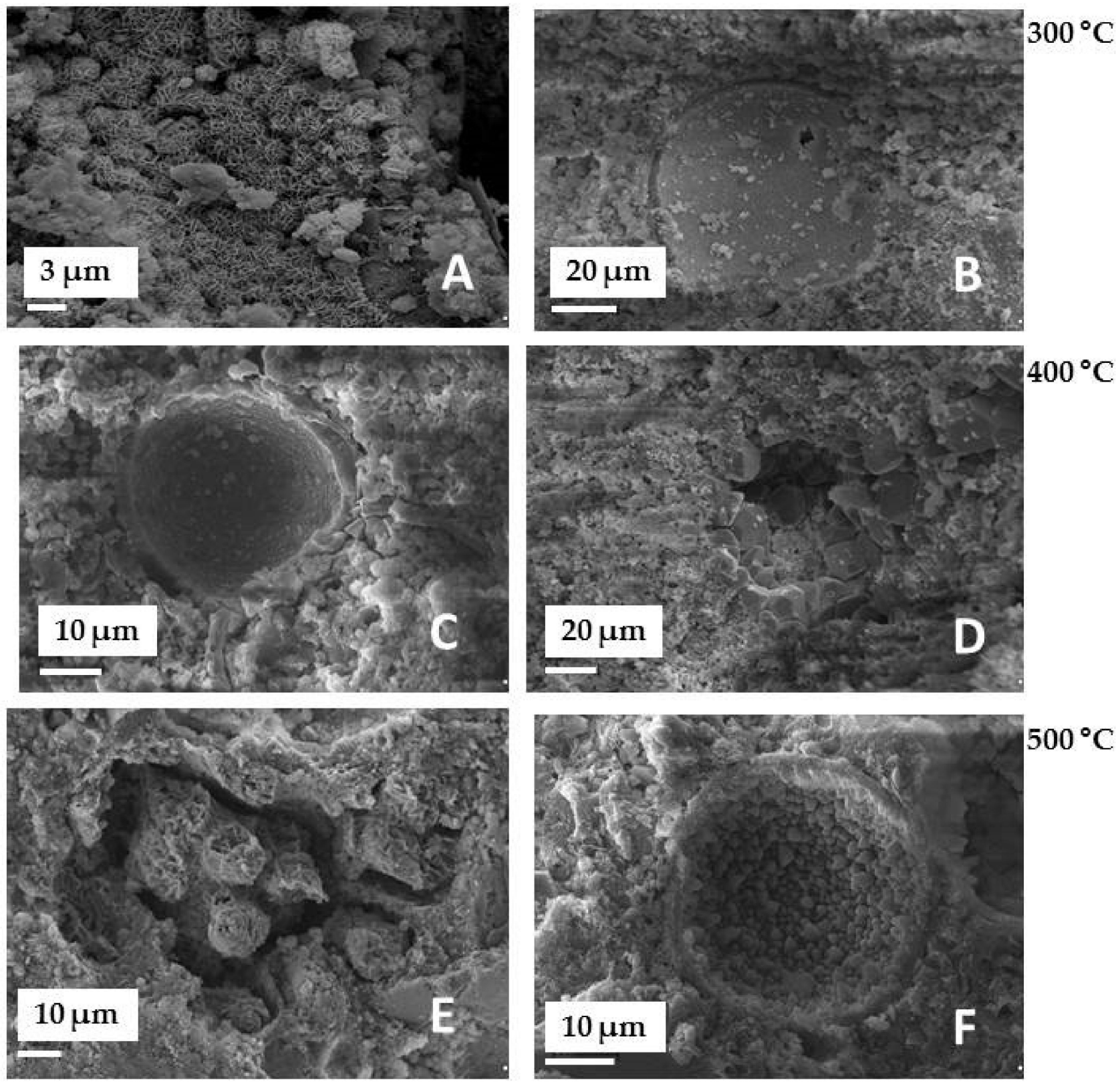

$400^{\circ} \mathrm{C}$
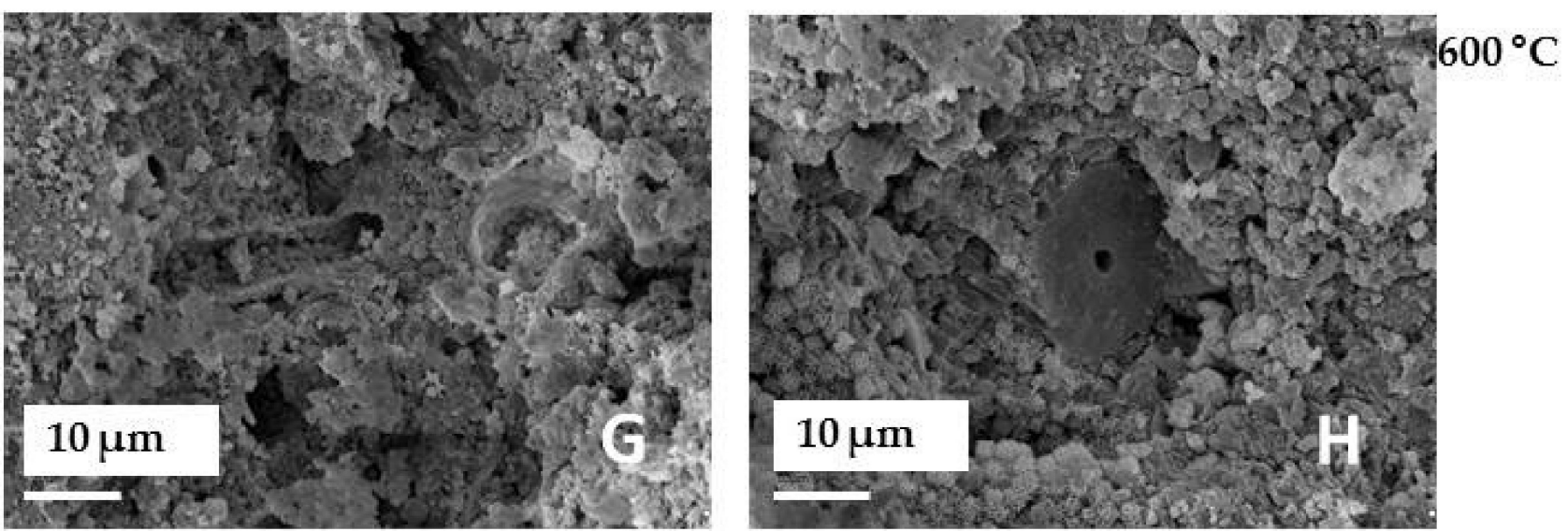

Figure 3. SEM images of opoka samples heat-treated at $300^{\circ} \mathrm{C}(\mathbf{A}, \mathbf{B}), 400{ }^{\circ} \mathrm{C}(\mathbf{C}, \mathbf{D}), 500{ }^{\circ} \mathrm{C}(\mathbf{E}, \mathbf{F})$, and $600{ }^{\circ} \mathrm{C}(\mathbf{G}, \mathbf{H})$. 

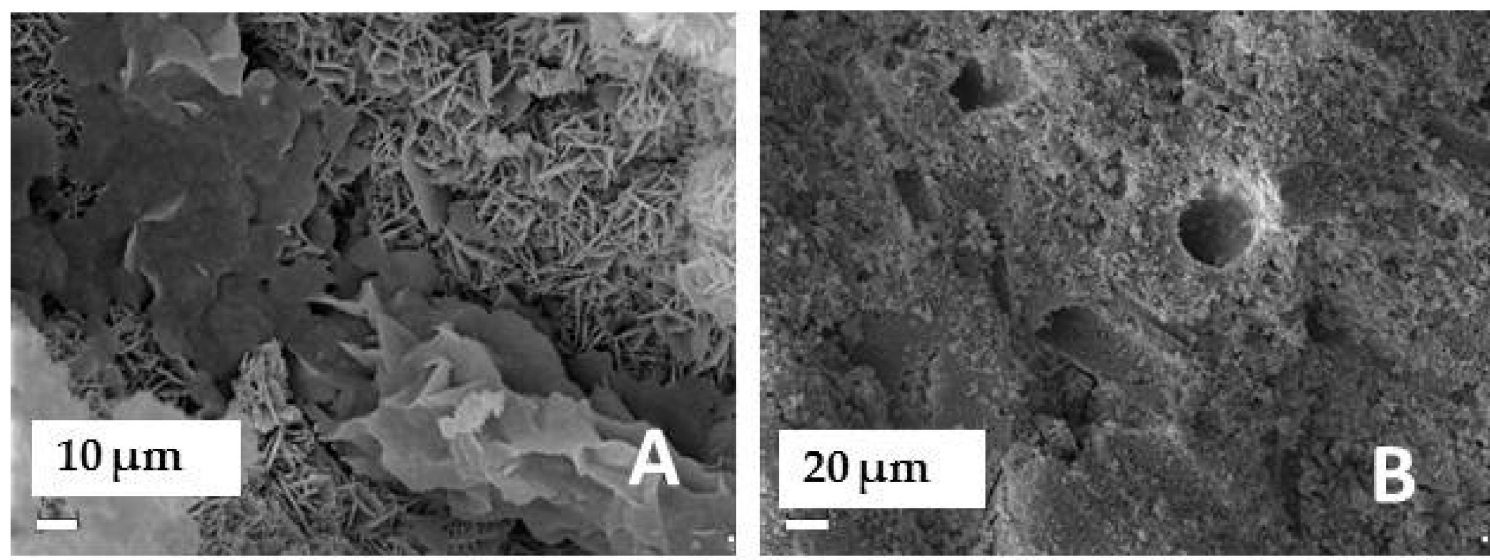

$700^{\circ} \mathrm{C}$
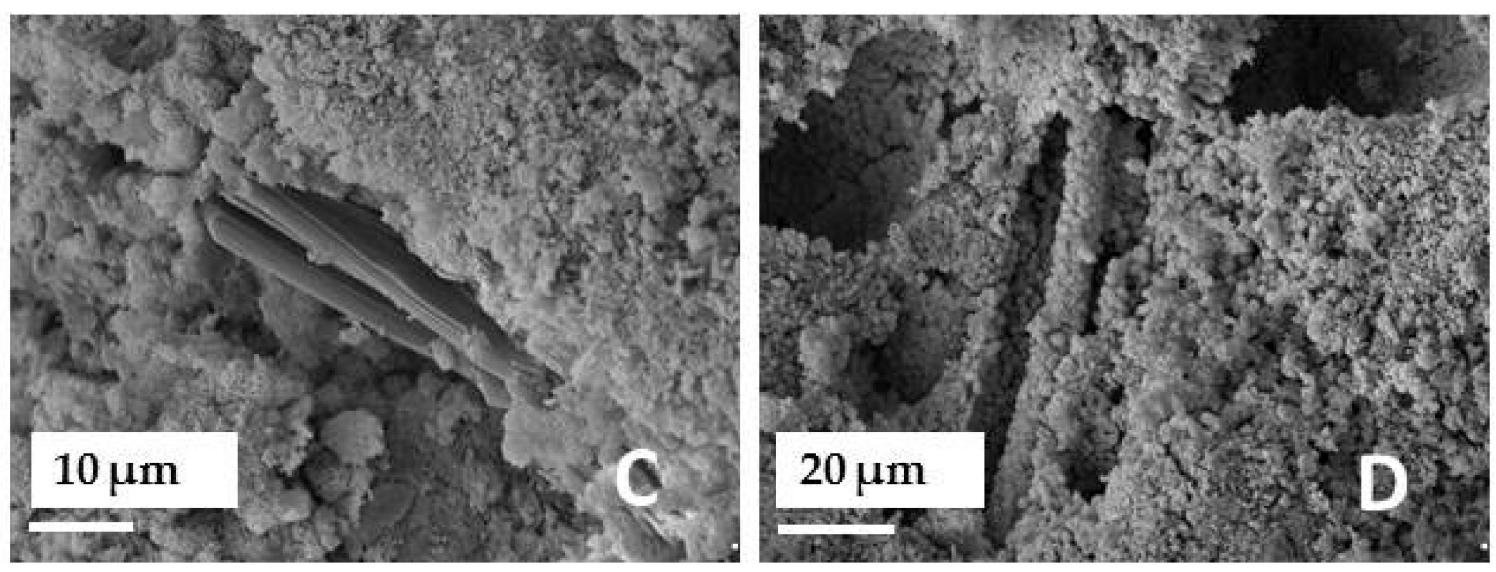

$800^{\circ} \mathrm{C}$
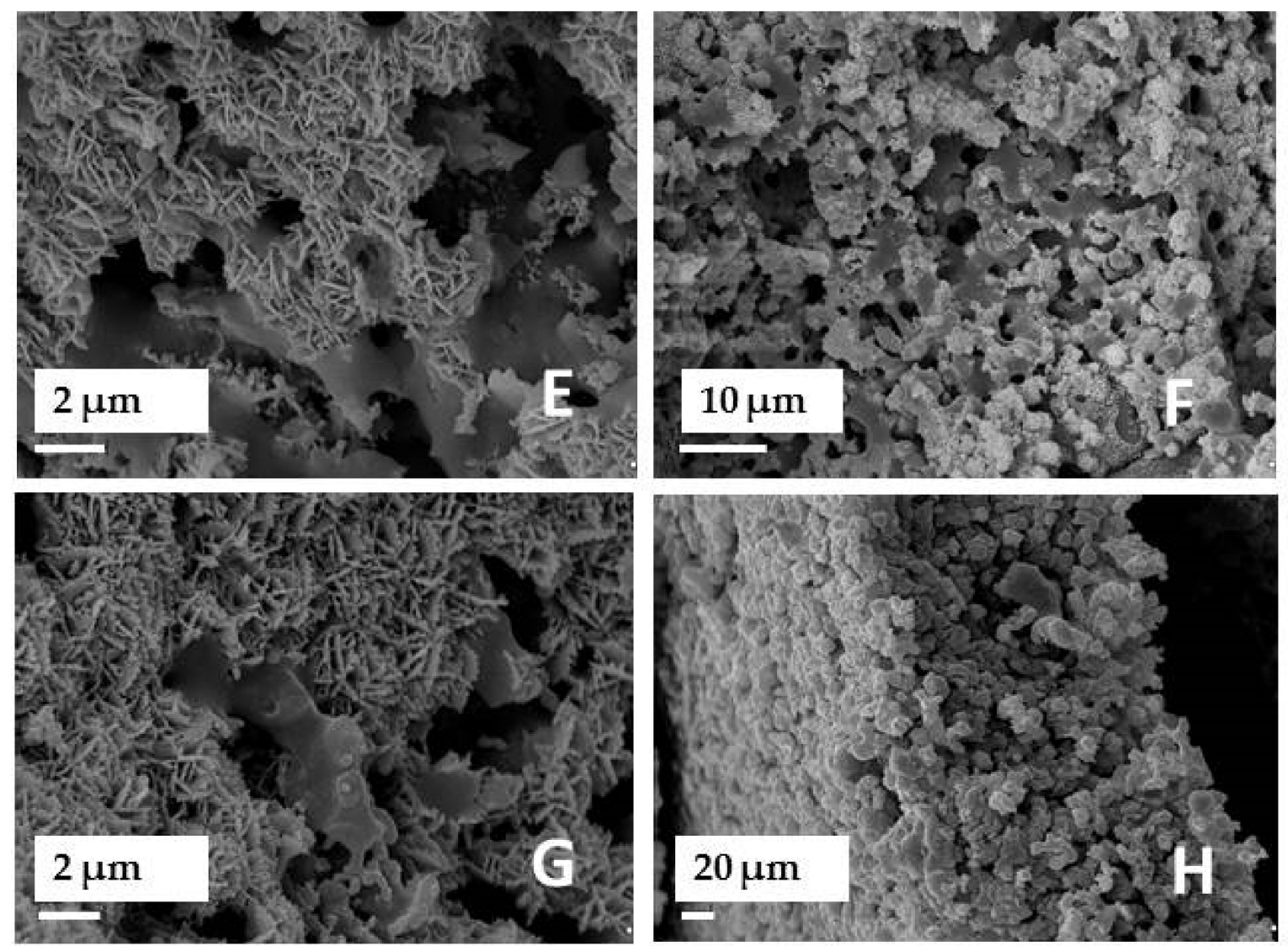

$900^{\circ} \mathrm{C}$

$1000^{\circ} \mathrm{C}$

Figure 4. SEM images of opoka samples heat-treated at $700{ }^{\circ} \mathrm{C}(\mathbf{A}, \mathbf{B}), 800^{\circ} \mathrm{C}(\mathbf{C}, \mathbf{D}), 900{ }^{\circ} \mathrm{C}(\mathbf{E}, \mathbf{F})$, and $1000{ }^{\circ} \mathrm{C}(\mathbf{G}, \mathbf{H})$. 
X-ray analysis of opoka samples (Figure 5) showed the presence of $\mathrm{CaCO}_{3}$ as the main crydtalline phase in the raw material, as well as $\mathrm{SiO}_{2}$ of quartz $(2 \theta=22,27,37)$ and tridimite $(2 \theta=21,27)$ structure [30]-Figure 6 . As the treatment temperature increases, a gradual decrease in the intensity of calcium carbonate reflections can be observed as a result of its thermal degradation, until their disappearance at the decomposition temperature of $\mathrm{CaCO}_{3}$. After annealing at $1000{ }^{\circ} \mathrm{C}$, the main phase is $\mathrm{CaO}-\mathrm{a}$ decomposition product of calcium carbonate. In addition, the diffractogram includes $\mathrm{SiO}_{2}$ reflections with the structure of quartz and cristobalite $(2 \theta=25,31,45,53)$ [31-33] - Figure 6. Wollastonite formation was not observed, which may be due to the stoichiometry of $\mathrm{SiO}_{2}$ and $\mathrm{CaO}$ components, which does not favor the formation of this material [34] and the presence of high-melting inorganic compounds in the rock-i.e., $\mathrm{Al}_{2} \mathrm{O}_{3}, \mathrm{TiO}_{2}, \mathrm{MgO}$, and $\mathrm{MnO}$-which increase the temperature of wollastonite formation [35].

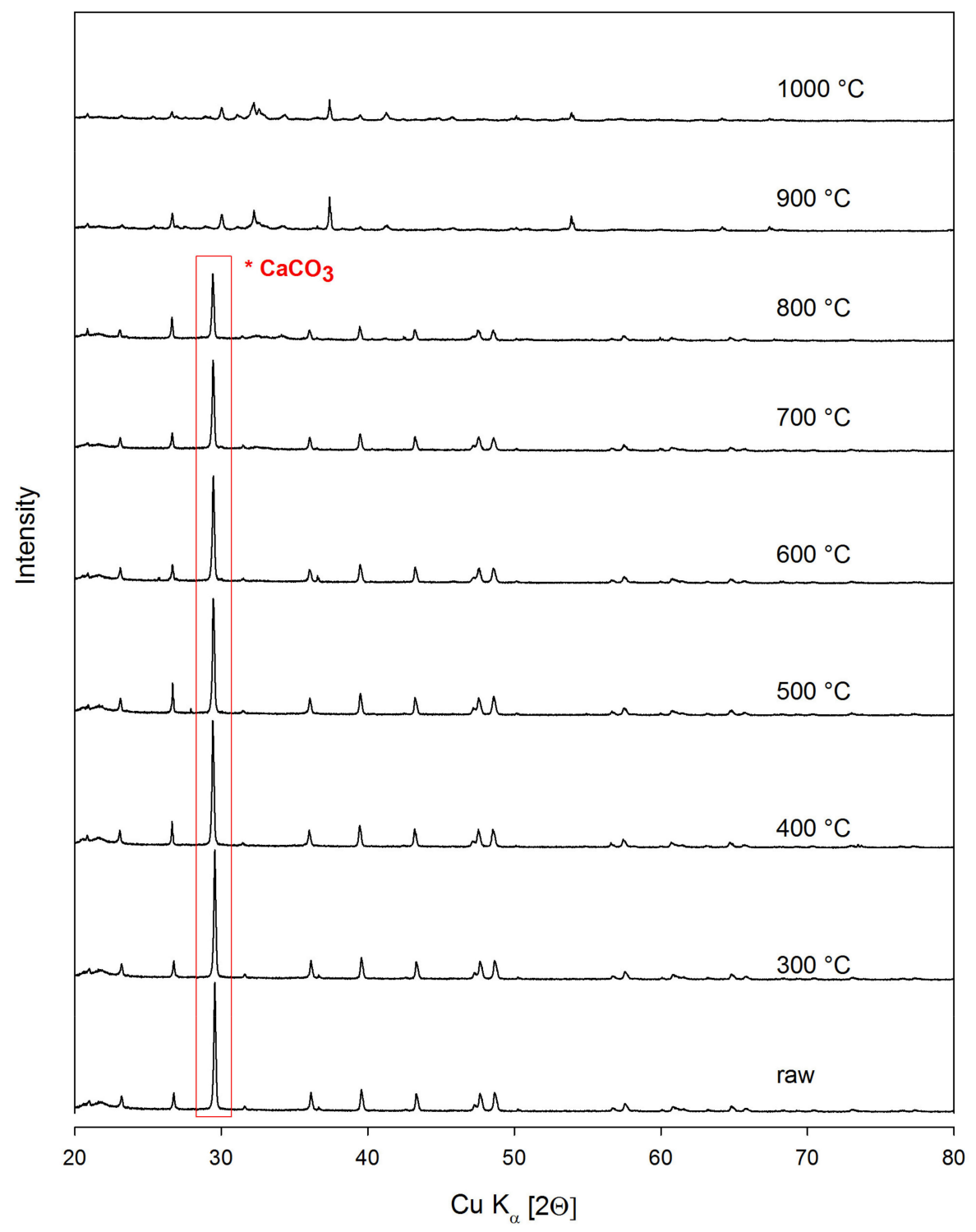

Figure 5. X-ray diffractograms of opoka samples after heat treatment. 

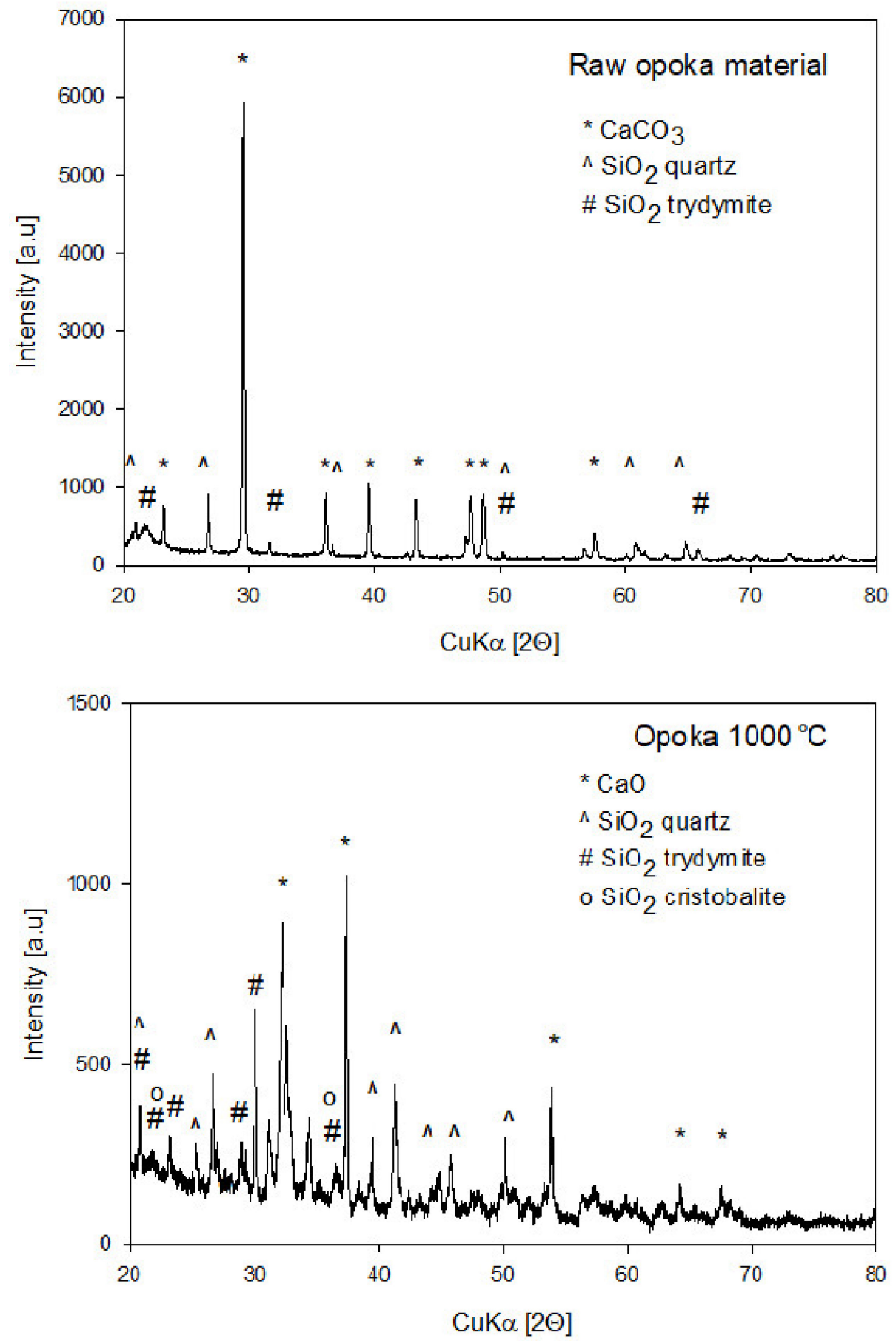

Figure 6. X-ray diffractograms of raw and $1000{ }^{\circ} \mathrm{C}$-treated opoka with phase analysis.

The absorption of infrared radiation by sedimentary rocks such as a rock depends on many factors, including: atomic mass, characteristics of interatomic bonds in the mineral structure, general symmetry of the unit cell, as well as the symmetry of the location of local atoms in the unit cell. This technique responds to both the long-range and shortrange ordering of minerals and has advantages over X-ray diffraction in this respect. The IR spectra can therefore be used to characterize and identify both crystalline and amorphous materials.

Figure 7 shows a summary of FT-IR spectra of opoka samples after high-temperature treatment. The bands at 717 (e), 870 (c), and 1411 (a) $\mathrm{cm}^{-1}$ wavelengths can be attributed to the presence of $\mathrm{CaCO}_{3}$ of the calcite structure $[36,37]$. However, the bands at the 458 (f), 788 (d) $\mathrm{cm}^{-1}$ wavelengths correspond to presence of $\mathrm{SiO}_{2}$ of a structure of quartz, tridimite, 
and cristobalite [38]. All these bands refer to the oscillation modes in the silicon-oxygen structure [39].

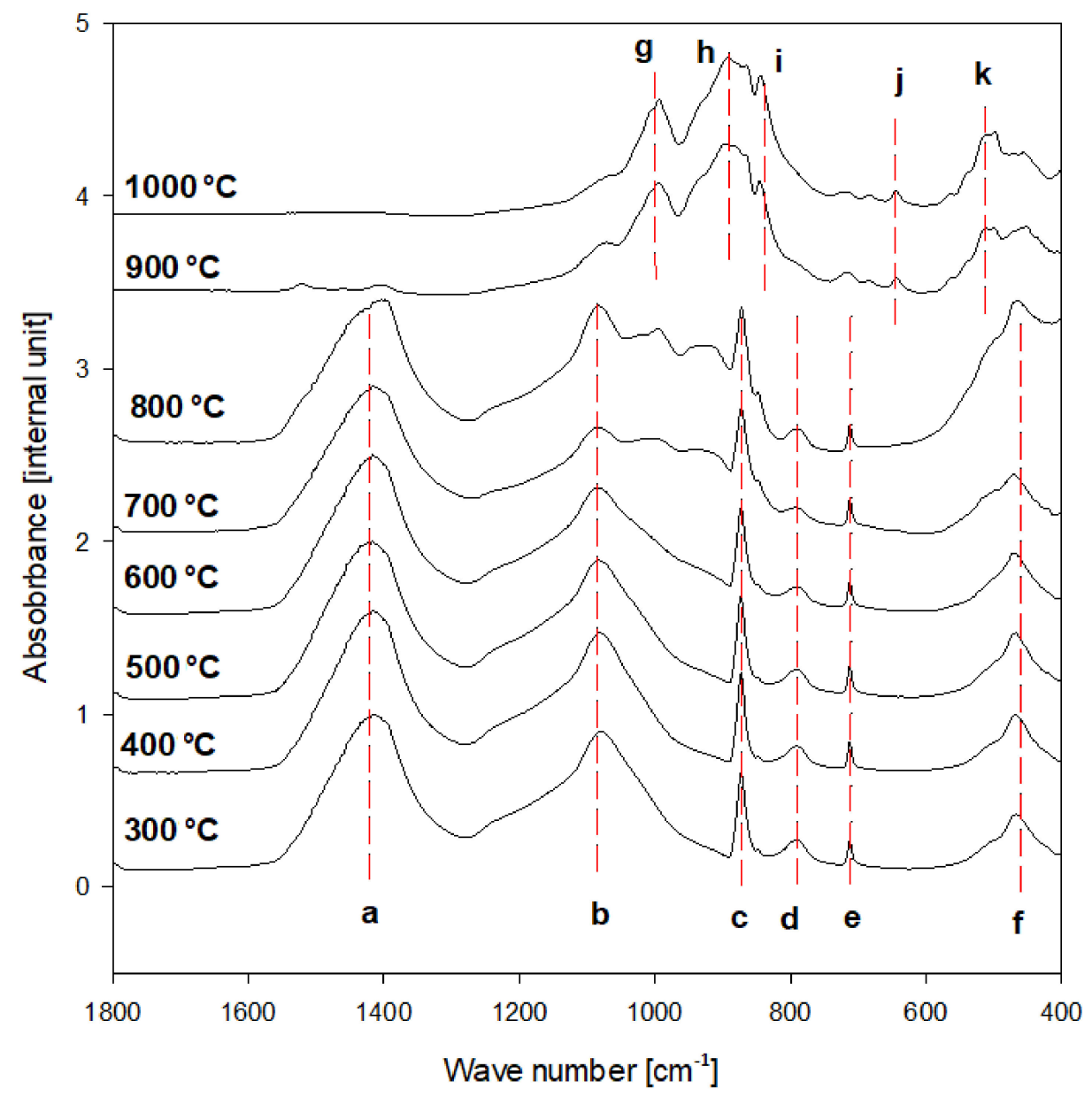

Figure 7. FTIR spectra of opoka samples after heat treatment.

The observable changes in the structure occur when the rock material is annealed at the temperature of $700{ }^{\circ} \mathrm{C}$. High temperature treatment causes the bands to disappear at the 717 (e) oraz $1070(\mathrm{~b}) \mathrm{cm}^{-1}$ wavelengths and formation of new bands at $1000 \mathrm{~cm}^{-1}$ (g) and $470 \mathrm{~cm}^{-1}(\mathrm{k})$ (asymmetric Si-O-Si stretching and bending vibrations [40]). Also, a disappearence of $1411 \mathrm{~cm}^{-1}$ (a) band occurs, which is related to the decomposition of calcium carbonate under the influence of high temperature (asymmetric vibrations of $\mathrm{CO}_{3}{ }^{2-}$ ). On the other hand, the bands formed after the temperature treatment at the wavelengths of $882 \mathrm{~cm}^{-1}(\mathrm{~h})$ and $847 \mathrm{~cm}^{-1}(\mathrm{i})$, are related to the presence of $\mathrm{SiO}_{2}$ with a cristobalite and quartz structure [38].

In the raw material two phases of different silicon and calcium content were observed, both containing $\mathrm{Ca}, \mathrm{Si}, \mathrm{Al}$, and $\mathrm{O}$ (Figure 8). After calcination, these phases underwent a transformation with a formation of three new phases (additional yellow colour visible in Figure 8) of varying $\mathrm{Ca} / \mathrm{Si}$ ratio (Table 1). The analysis of phase composition allows for observation of oxygen content decrease, which is a result of $\mathrm{CaCO}_{3}$ decomposition with $\mathrm{CO}_{2}$ release. 

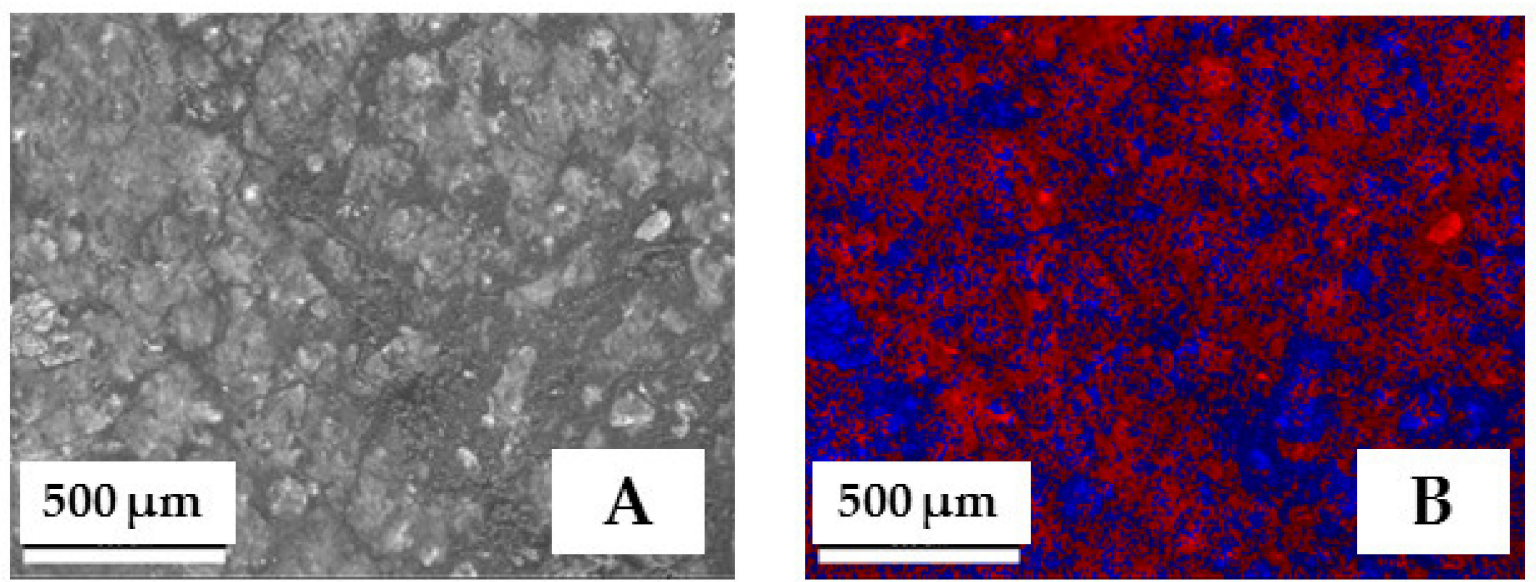

Figure 8. SEM-EDS of raw opoka material (A) SEM image, (B) EDS map; blue phase: CaK/SiK/OK, red phase SiK/CaK/OK.

Table 1. SEM-EDS analysis of the opoka samples.

\begin{tabular}{|c|c|c|c|c|}
\hline & Phase & CaK/SiK/OK & \multicolumn{2}{|c|}{$\mathrm{SiK/CaK/OK}$} \\
\hline & \multicolumn{4}{|c|}{ Atomic Content (\%) } \\
\hline \multirow{8}{*}{ Raw } & $\mathrm{O}$ & 73.23 & \multicolumn{2}{|c|}{73.12} \\
\hline & $\mathrm{Mg}$ & - & \multicolumn{2}{|c|}{-} \\
\hline & $\mathrm{Al}$ & 0.60 & \multicolumn{2}{|c|}{0.88} \\
\hline & $\mathrm{Si}$ & 8.25 & \multicolumn{2}{|c|}{13.93} \\
\hline & $\mathrm{Ca}$ & 17.92 & \multicolumn{2}{|c|}{12.06} \\
\hline & Total phase & 45.00 & \multicolumn{2}{|c|}{55.00} \\
\hline & Phase & CaSiO-1 & CaSiO-2 & CaSiO-3 \\
\hline & \multicolumn{4}{|c|}{ Atomic Content (\%) } \\
\hline \multirow{6}{*}{$1000^{\circ} \mathrm{C}$} & $\mathrm{O}$ & 60.65 & 64.93 & 63.63 \\
\hline & $\mathrm{Mg}$ & 0.23 & 0.19 & 0.32 \\
\hline & $\mathrm{Al}$ & 0.69 & 0.87 & 0.34 \\
\hline & $\mathrm{Si}$ & 12.77 & 16.80 & 5.76 \\
\hline & $\mathrm{Ca}$ & 25.66 & 17.21 & 29.94 \\
\hline & Total phase & 54.00 & 22.00 & 24.00 \\
\hline
\end{tabular}

The phase changes occurring in the material under the influence of high-temperature treatment are also visible under SEM-EDS imaging. (Figures 8 and 9). Thermal degradation of calcite allows for deagglomeration of silica microparticles, which later improved the dispersion of the filler in the polypropylene composites prepared during the study. Table 1 shows the results of the elemental analysis by SEM-EDS for the starting material and after temperature treatment at $1000^{\circ} \mathrm{C}$.

The results of the $\mathrm{pH}$ measurement of the opoka samples (Table 2), both in the demineralized water and in the $1 \mathrm{M} \mathrm{KCl}$ environment, indicate an increase in the alkalinity of the samples as the annealing temperature increases. Calcium oxide formation during $\mathrm{CaCO}_{3}$ decomposition is responsible for this effect. The formation of a strongly basic component may be important when designing composites with sorption functionalitye.g., for heavy metal ions. The $\mathrm{pH}$ characterization of the material indicates that the tested raw material does not have the character of ion exchangeability typically observed for soils. This indicates that the material in its structure has mainly geologically transformed components and is also caused by the lack of aluminosilicates in the composition of opoka. 

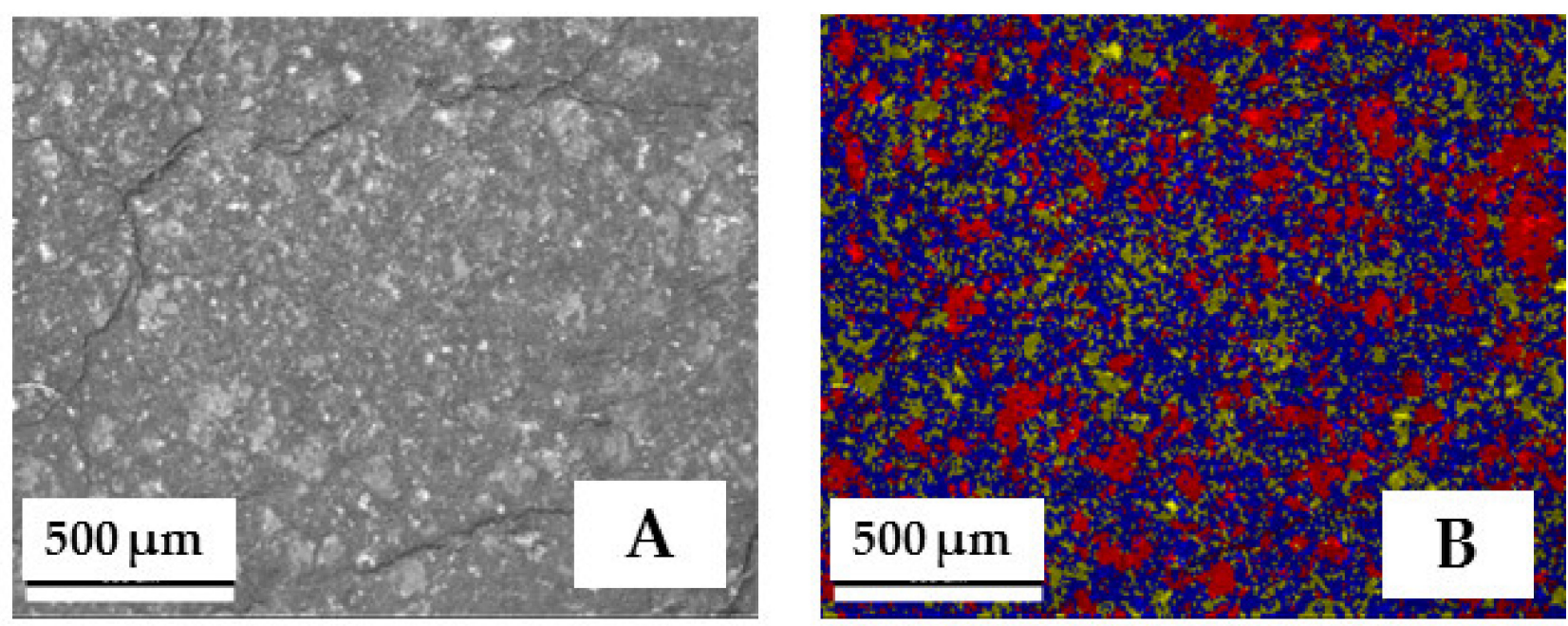

Figure 9. SEM-EDS of opoka after heat treatment at $1000^{\circ} \mathrm{C}$. (A) SEM image, (B) EDS map; blue phase: CaSiO-1, yellow phase: $\mathrm{CaSiO}-2$, red phase: $\mathrm{CaSiO}-3$.

Table 2. $\mathrm{pH}$ value extract of opoka samples.

\begin{tabular}{ccc}
\hline Sample & $\mathbf{p H}$ in $\mathbf{H}_{\mathbf{2}} \mathbf{O}$ & $\mathbf{p H}$ in $\mathbf{1} \mathbf{~ M ~} \mathbf{~ C l}$ \\
\hline Raw & 8.35 & 8.41 \\
$300^{\circ} \mathrm{C}$ & 10.39 & 10.03 \\
$400^{\circ} \mathrm{C}$ & 10.19 & 9.95 \\
$500^{\circ} \mathrm{C}$ & 10.28 & 10.12 \\
$600^{\circ} \mathrm{C}$ & 10.71 & 11.00 \\
$700^{\circ} \mathrm{C}$ & 11.18 & 11.47 \\
$800^{\circ} \mathrm{C}$ & 12.29 & 12.67 \\
$900^{\circ} \mathrm{C}$ & 12.62 & 12.81 \\
$1000^{\circ} \mathrm{C}$ & 12.65 & 12.76 \\
\hline
\end{tabular}

Changes in the values of the surface area of the filler as a function of the temperature of opoka samples are summarized in Table 3. The curves of the adsorption-desorption experiments are presented in Figure 10.

Table 3. Textural parameters of heat-treated opoka samples.

\begin{tabular}{cccccc}
\hline $\begin{array}{c}\text { Sample } \\
\text { Name }\end{array}$ & $\begin{array}{c}\text { BET Surface } \\
\text { Area }\left(\mathbf{m}^{\mathbf{2}} \mathbf{/ g}\right)\end{array}$ & $\begin{array}{c}\text { Pore Volume A } \\
\left(\mathbf{c m}^{\mathbf{3}} \mathbf{g}\right)\end{array}$ & $\begin{array}{c}\text { Pore Volume D } \\
(\mathbf{c m} \mathbf{3} / \mathbf{g})\end{array}$ & $\begin{array}{c}\text { Pore Size A } \\
(\mathbf{n m})\end{array}$ & $\begin{array}{c}\text { Pore Size D } \\
\mathbf{( n m})\end{array}$ \\
\hline Raw & 12.1 & 0.04 & 0.04 & 14.7 & 12.4 \\
$300^{\circ} \mathrm{C}$ & 31.4 & 0.09 & 0.09 & 113.6 & 9.9 \\
$400^{\circ} \mathrm{C}$ & 30.3 & 0.09 & 0.09 & 114.1 & 1 \\
$500^{\circ} \mathrm{C}$ & 31.2 & 0.09 & 0.09 & 115.9 & 10.1 \\
$600^{\circ} \mathrm{C}$ & 24.9 & 0.08 & 0.08 & 127.6 & 11.1 \\
$700^{\circ} \mathrm{C}$ & 26.9 & 0.08 & 0.08 & 119.5 & 10.4 \\
$800^{\circ} \mathrm{C}$ & 21.7 & 0.07 & 0.07 & 118.3 & 1 \\
$900^{\circ} \mathrm{C}$ & 5.7 & 0.02 & 0.02 & 127.2 & 10.1 \\
$1000^{\circ} \mathrm{C}$ & 3.4 & 0.01 & 0.01 & 151.1 & 11.9 \\
\hline
\end{tabular}

Pore volume A—calculated from the adsorption branch of isotherm; Pore volume D—calculated from the desorption branch of isotherm; Pore size D—calculated from the desorption branch of isotherm. 

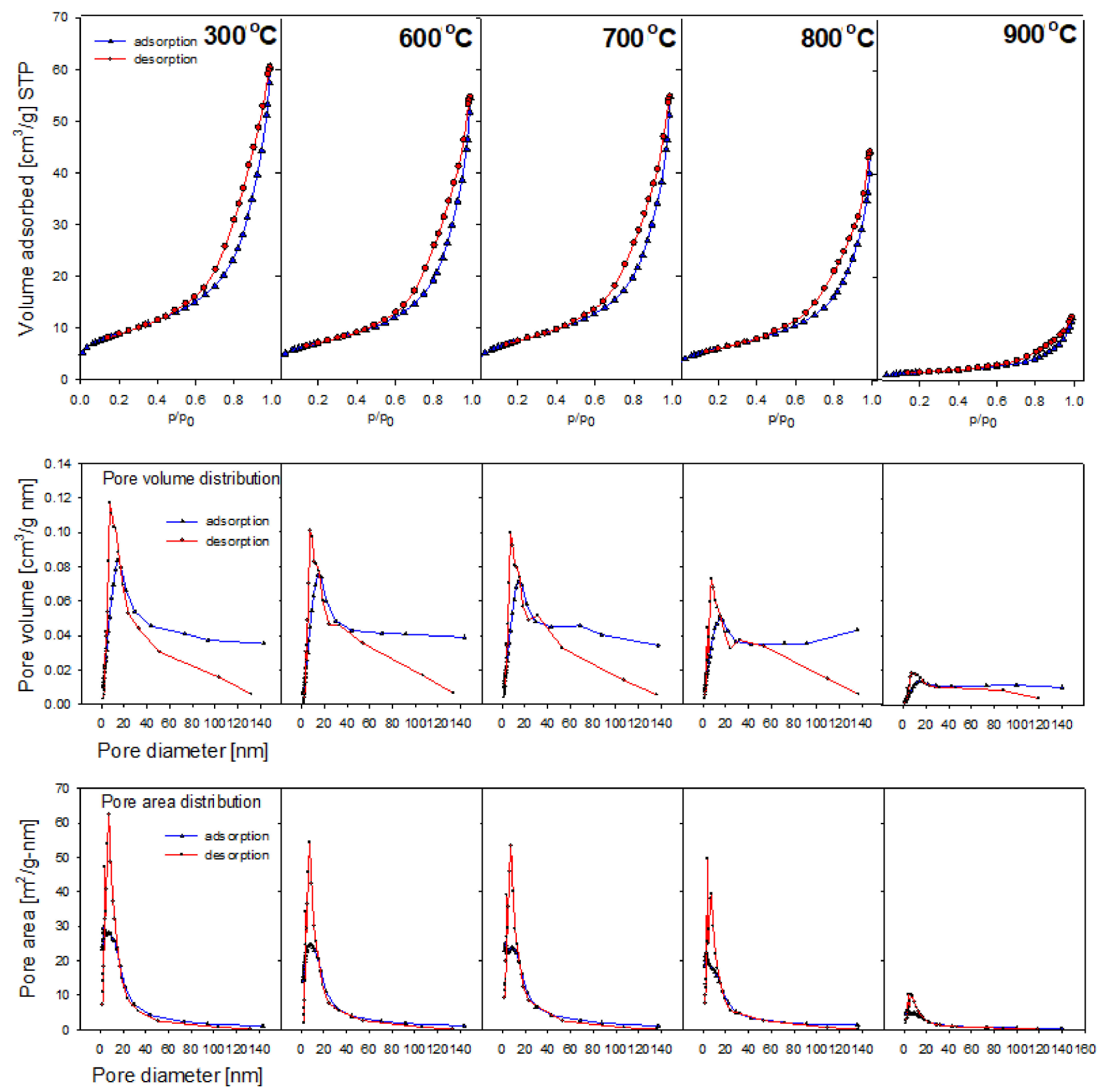

Figure 10. Nitrogen adsorption-desorption curves, pore volume distribution curves, and pore area distribution curves for opoka samples calcinated at different temperatures.

The raw material is characterized by a low surface area, and thermal treatment thereof at only $300{ }^{\circ} \mathrm{C}$ already causes more than a two-fold increase in this value. The surface area remains at $\sim 31 \mathrm{~m}^{2} / \mathrm{g}$ up to $500{ }^{\circ} \mathrm{C}$. Above this temperature, this parameter is reduced down. A critical point is observed above $800{ }^{\circ} \mathrm{C}$, where decomposition of $\mathrm{CaCO}_{3}$ accompanied by degradation of porous structure occurs. It is related both to the phase change of the material in the critical point, described earlier in the SEM analysis, and the collapse of pores and micropores (Table 3). Similar relationships occur when analyzing pore surface, size, and volume. It was also observed in Brogowski's work [22].

The opoka rock grinding process influences the grain size distribution, reducing the proportion of larger particles with a size of $1000 \mu \mathrm{m}$ in favor of particles with a diameter of about $40 \mu \mathrm{m}$ (Figure 11). This particle size appears to be the major one in the sample after grinding for $40 \mathrm{~h}$. The proportion of particles with smaller diameters also increases, with a 
maximum volume frequency of $5 \mu \mathrm{m}$. Particles with smaller diameters are important for the use of the material as a filler

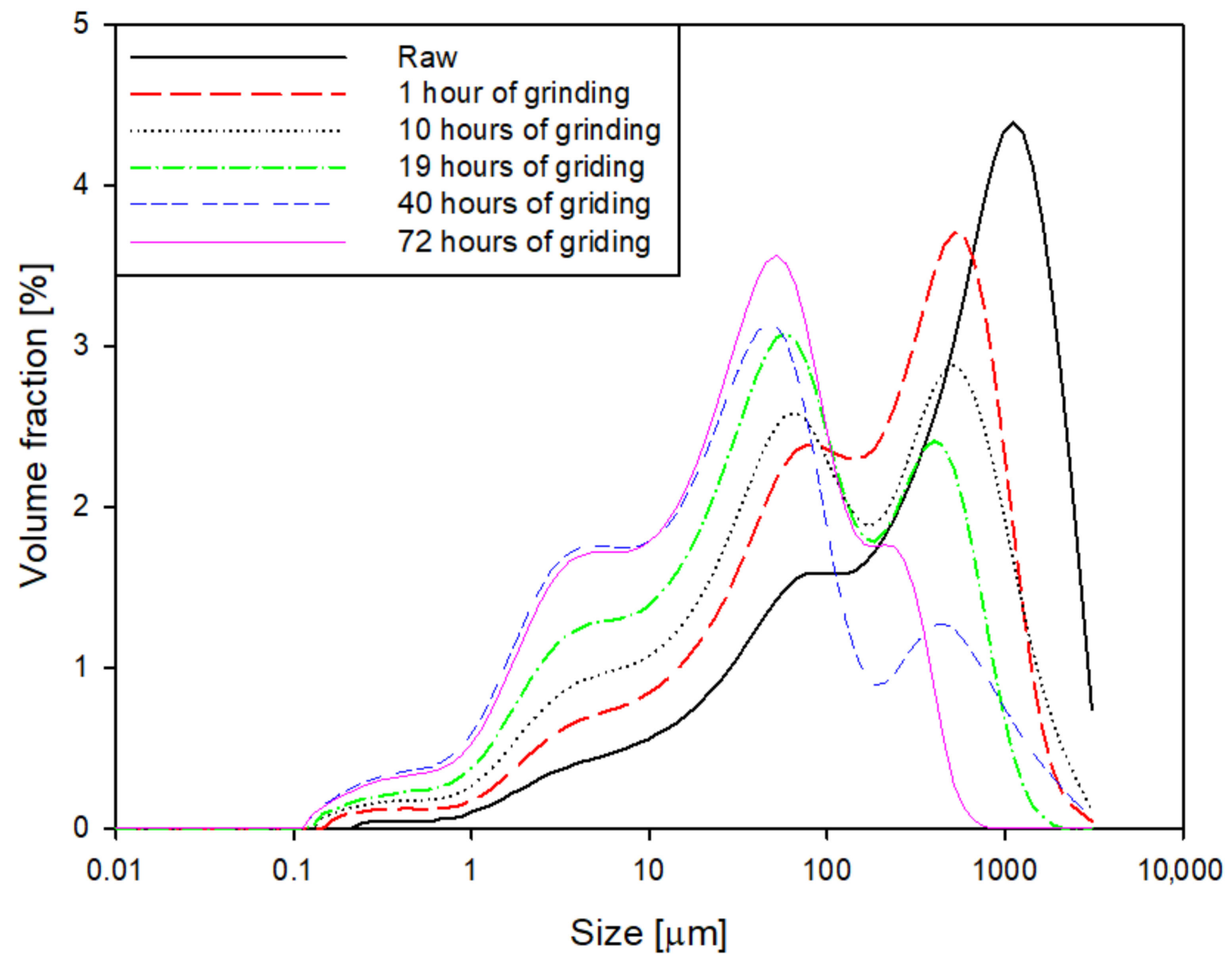

Figure 11. Effect of grinding time on rock grain size distribution of opoka.

Figure 12 shows an example of TG-MS (A) and TG-DTA (B) curves of the opoka sample thermal analysis. An initial weight loss of $\sim 1 \mathrm{wt} \%$ until the temperature reaches $300{ }^{\circ} \mathrm{C}$ is mainly attributed to desorption of water (Figure $12 \mathrm{~A}, \mathrm{~m} / \mathrm{z}=18$ ) and organic species physically adsorbed on the particle surface. Thereafter, at $\sim 60{ }^{\circ} \mathrm{C}$, an onset of the main thermal event is visible (Figure 12B), which is the thermal decomposition of $\mathrm{CaCO}_{3}$ with $\mathrm{CO}_{2}$ release according to the equation 1 (Figure $12 \mathrm{~A}, \mathrm{~m} / \mathrm{z}=44$ ) [41]. The total weight loss is $32.7 \%$, which, after subtracting $1 \%$ of the loss associated with water desorption, is the product of the decomposition of $\mathrm{CaCO}_{3}$ to $\mathrm{CaO}$ and $\mathrm{CO}_{2}$.

$$
\mathrm{CaCO}_{3}(100 \%) \rightarrow \mathrm{CaO}(56 \%)+\mathrm{CO}_{2}(44 \%)
$$

On the basis of the average of 20 TG measurements, the amount of $\mathrm{CO}_{2}$ evolved from the tested material was calculated at the level of $22.8 \%$. This result gives the $\mathrm{CaCO}_{3}$ content at the level of $51.8 \%$ and the Ca content at the level of $26.8 \%$. This is in line with the SEM-EDS studies (Table 1). Thus, it was proved that the thermogravimetric method is the most accurate in calculating the $\mathrm{CaCO}_{3}$ content in limestone-based rocks. 

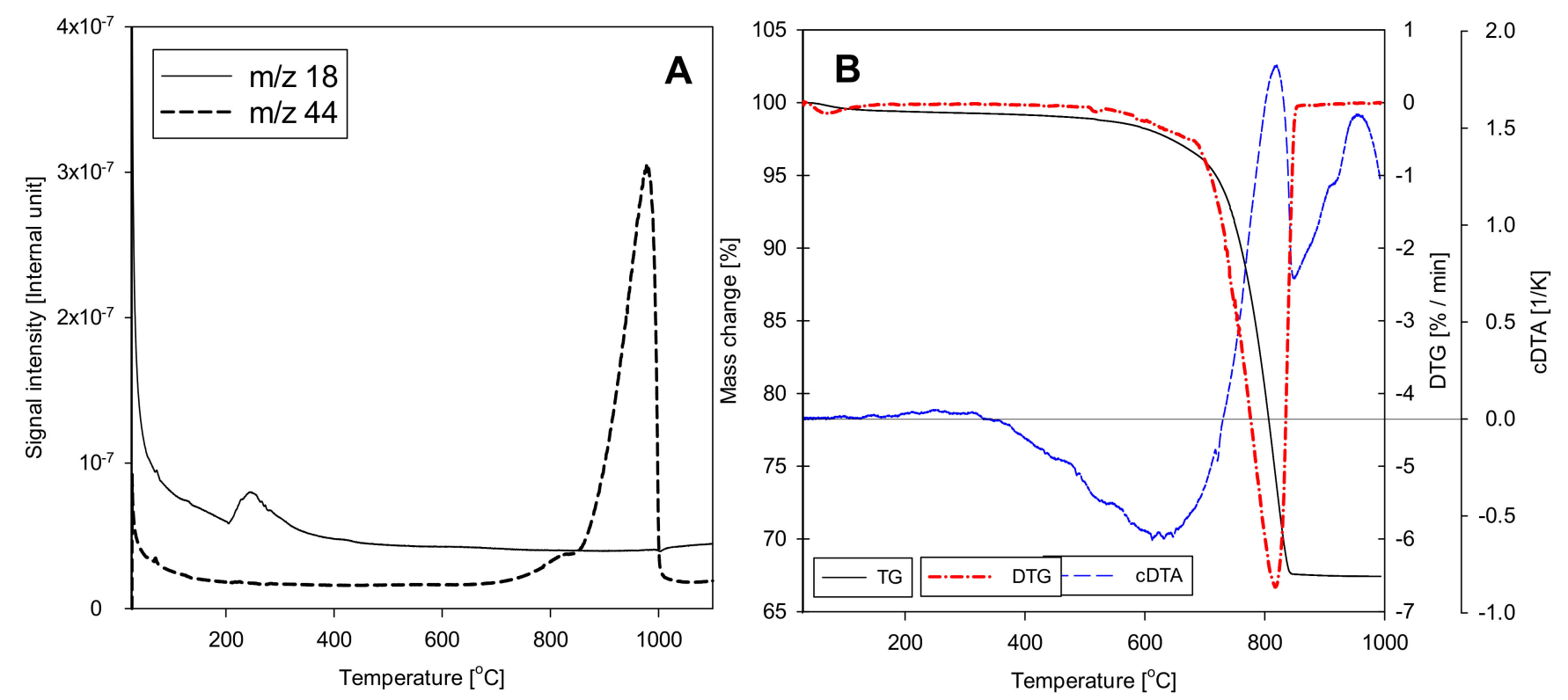

Figure 12. Thermal analysis of opoka sample. (A) TG-MS, (B) TG-DTA.

Due to the fact that opoka contains calcite and silica, the material can be used as a natural polymer filler [42] improving the parameters of the composite obtained and increasing its applicability. To investigate the possibility of using opoka as a filler, samples of polypropylene $\mathrm{PP}$ ) and its composites containing $5 \mathrm{wt} \%$ of the following materials were prepared: calcium carbonate (C5) and Aerosil 200 silica (A5) for reference filler materials, and opoka in thermally untreated form (O5), as well as calcinated at the temperatures of $800{ }^{\circ} \mathrm{C}\left(\mathrm{O} 5 \_800\right)$ and $1000{ }^{\circ} \mathrm{C}\left(\mathrm{O} 5 \_1000\right)$. Measurements of the mechanical properties under tensile tests and three-point flexural tests were carried out, and their results are summarized in Table 4.

Table 4. Mechanical properties of PP composites for tensile and flexural tests.

\begin{tabular}{ccccccc}
\hline Sample & $\mathbf{E}_{\mathbf{t}}, \mathbf{G P a}$ & $\boldsymbol{\sigma}_{\mathbf{M}}, \mathbf{M P a}$ & $\boldsymbol{\varepsilon}_{\mathbf{B}}, \boldsymbol{\%}$ & $\mathbf{E}_{\mathbf{f}}, \mathbf{G P a}$ & $\mathbf{F}_{\mathbf{f c}}, \mathbf{N}$ & $\mathbf{H S},{ }^{\mathbf{0}} \mathbf{S h}$ \\
\hline PP & $1.29 \pm 0.01$ & $32.3 \pm 0.41$ & $45.2 \pm 3.58$ & $1.30 \pm 0.01$ & $54.9 \pm 0.76$ & $61.8 \pm 0.1$ \\
C5 & $1.46 \pm 0.01$ & $33.5 \pm 0.05$ & $28.6 \pm 2.60$ & $1.39 \pm 0.02$ & $59.3 \pm 0.87$ & $62.2 \pm 0.1$ \\
A5 & $1.35 \pm 0.03$ & $34.2 \pm 0.14$ & $30.0 \pm 3.75$ & $1.37 \pm 0.01$ & $63.1 \pm 0.61$ & $61.9 \pm 0.2$ \\
O5 & $1.49 \pm 0.01$ & $32.6 \pm 0.31$ & $24.2 \pm 5.73$ & $1.38 \pm 0.02$ & $61.5 \pm 0.54$ & $63.8 \pm 0.1$ \\
O5_800 & $1.42 \pm 0.02$ & $32.3 \pm 0.35$ & $29.4 \pm 3.25$ & $1.38 \pm 0.02$ & $59.9 \pm 0.48$ & $62.6 \pm 0.1$ \\
O5_1000 & $1.38 \pm 0.02$ & $32.0 \pm 0.35$ & $30.2 \pm 5.52$ & $1.33 \pm 0.02$ & $58.8 \pm 0.25$ & $62.1 \pm 0.2$
\end{tabular}

$\mathrm{E}_{\mathrm{t}}$-Young's modulus; $\sigma_{\mathrm{M}}$-stress at maximum load; $\varepsilon_{\mathrm{B}}$-elongation at break; $\mathrm{E}_{\mathrm{f}}$-flexural modulus; $\mathrm{F}_{\mathrm{fc}}$-yield stress; HS-Shore hardness.

The obtained results showed the expected increase in stiffness of all types of tested composites in relation to the neat polypropylene used, which is normal for such composites [43-46]. The introduction of all types of tested powder fillers into the polypropylene matrix increases the modulus and hardness of composites with a simultaneous reduction in their elongation at break in relation to PP (for example, $\mathrm{E}_{\mathrm{t}}$ increased by approx. $200 \mathrm{MPa}$ and HS by approx. $20^{\circ} \mathrm{Sh}$, compared to PP and $\mathrm{O} 5 ; \varepsilon_{\mathrm{B}}$ decreased by $21 \%$ ). Improvement in the stiffness and hardness of composites results from the introduction of rigid regions in the form of powder fillers into the polymer matrix. At the same time, these regions disturb the continuity of the polymer matrix structure and reduce the elongation at break. Discontinuities in the material structure of composites, the so-called micronotches caused by the presence of the powder filler, are the sites of stress concentration. In these sites, material decohesion begins in the form of developing microcracks. Additional stress concentration, which is the source of the material cracking, may take place in the polymer-filler interface. The decrease in elongation at break of the tested composites may be the result 
of poor adhesion of the fillers to the polymer matrix, poor dispersion of their particles in a non-polar polyolefin matrix and the ability to form agglomerates characterized by low adhesion to the matrix [45]. The inorganic powder filler may also be characterized by the inability to transmit the stresses exerted on the polymer matrix, as a result of which a decrease in elongation at break will also be observed. With regard to the commercially used calcium carbonate and silica, the use of a hybrid filler in the form of a opoka (O5) allows for the production of composite materials with a higher Young's modulus (approx. 30 and $140 \mathrm{MPa}$, when compared to $\mathrm{C} 5$ and A5) and higher hardness (1.6 and $1.9^{\circ} \mathrm{Sh}$ with respect to $\mathrm{C} 5$ and A5) yet having a lower elongation at break, with other mechanical parameters being at comparable levels to the reference samples. The reported research results are very promising. The important aspect of powder filler characteristics is the grain size-for composite materials of satisfactory mechanical properties, the smaller, the better [46-48]. The mineral material used in this research is characterized by a much larger average grain size in relation to reference calcium carbonate and silica, which suggests that if an opoka grade with a lower $d_{50}$ than the one used in this study was used for the production of composites, materials with much better mechanical properties could be obtained.

When analyzing the obtained test results in the context of the calcination process, it was noticed that, along with the increase of the heat treatment temperature, the mechanical properties of the composites prepared with the heat-treated filler showed a very slightly downward trend when it comes to stress at maximum load and yield stress. The biggest difference, however-i.e., a decrease by approx. $110 \mathrm{MPa}$ and $1.7^{0} \mathrm{Sh}$-was recorded for the Young's modulus and Shore hardness, when comparing O5 and O5_1000. For the remaining mechanical parameters, the differences are smaller. The observed trend is most likely due to changes in the surface area and pores area (having an impact on the filler wetting action by the polymer matrix) (Table 3) and the surface morphology (Figures 3 and 4 ). In the literature reports, it was shown that the greater the BET and the smaller the filler pore area, the higher the mechanical properties of the composite [49-51]. Nevertheless, calcined opoka composites were characterized by higher ductility, as smaller reduction of $\varepsilon B$ was observed in comparison to raw opoka and chalk, and the results were comparable to Aerosil filler. This is likely due to less structural defects imparted by the filler, and a result of thermal deterioration of silica aggregates during calcination (Figure 13).

Summarizing the presented results of the research on the mechanical properties, it can be stated that the opoka rock, both in the form of raw material (ground) and postproduction waste (small-grain fraction obtained from sieving process), formed during the production of sorbent used to purify water from phosphates; as for this purpose, the material is also calcined at a temperature of $1000^{\circ} \mathrm{C}$. It can be used as a filler for commercial polymers to produce composites with comparable or better mechanical properties, when compared to the commonly used calcium carbonate and silica. It should also be emphasized that polypropylene/opoka composites are characterized by good processability, which is described in detail in an earlier work [42].

For raw material, the best dispersion of carbonate phase was observed, while solid particles are rich in $\mathrm{SiO}_{2}$, most likely being the quartz phase particles (Figure 13). On the other hand, the agglomerations of silicon and calcium phases seen in the O_1000 system are aggregates of the filler caused by secondary filler agglomeration-it is visible that the material does not form solid particles in this system. The secondary agglomeration is due to the polar character of the material used, which is typical for mineral fillers used in polymer composite preparation with no prior chemical surface treatment. 

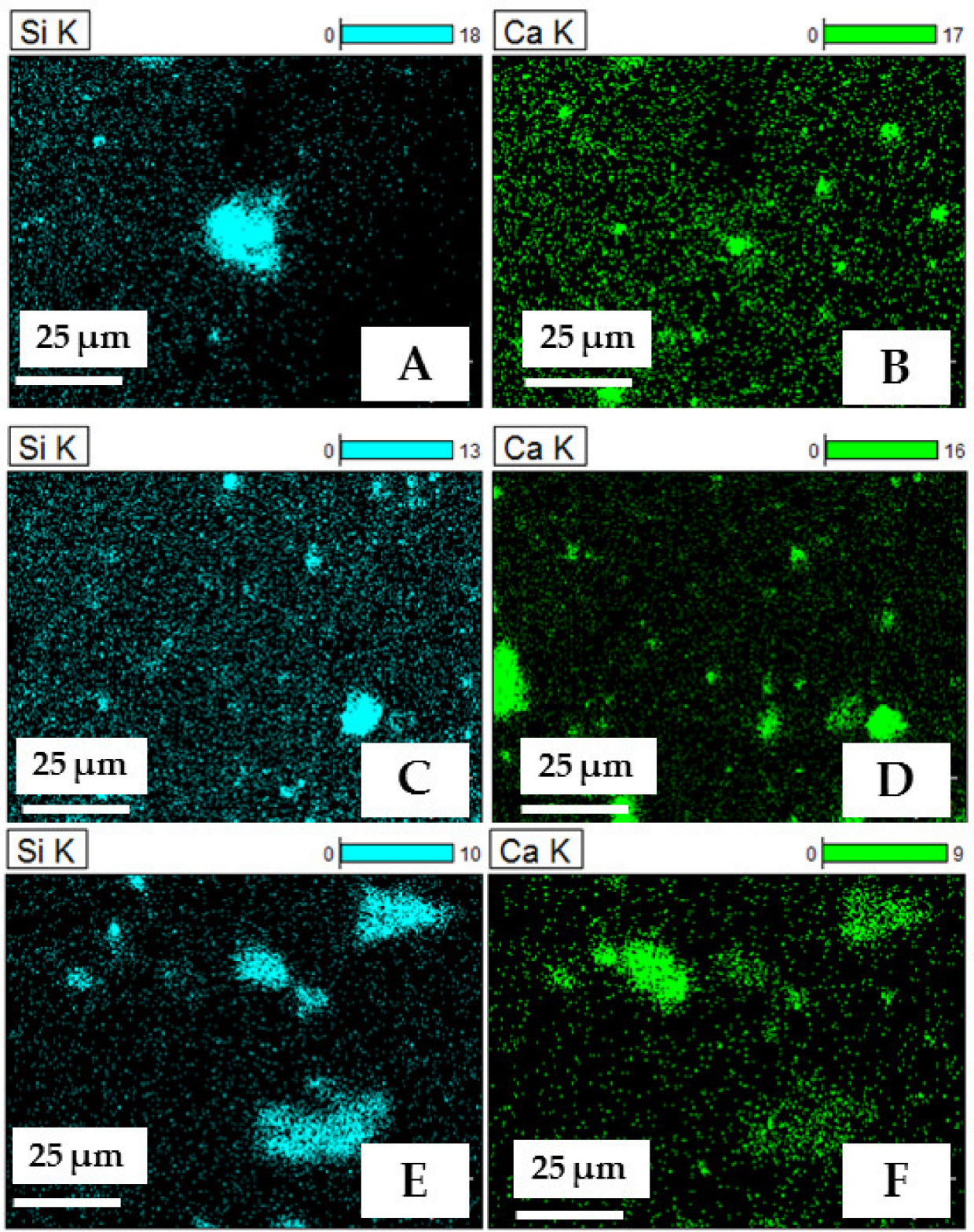

Figure 13. SEM-EDS images of opoka/polypropylene composite samples: raw opoka/PP (A,B), opoka calcined at $800^{\circ} \mathrm{C} / \mathrm{PP}(\mathbf{C}, \mathbf{D})$, opoka calcined at $1000^{\circ} \mathrm{C} / \mathrm{PP}(\mathbf{E}, \mathbf{F})$.

\section{Conclusions}

This work presents a comprehensive characterization of the opoka rock as a mineral filler for thermoplastic polymers. The obtained results show that the heavy opoka grade is a hard rock, resistant to abrasion and grinding processes, which needs consideration in case of planning the technological process for its application in polymer composite systems. The important conclusions coming from the characterization of opoka physicochemical properties and behaviour as a filler are:

(1) It has been shown that opoka can be an effective hybrid filler in thermoplastic systems. The mechanical properties of the composite are comparable to those of the reference materials used (Aerosil 200 silica and $\mathrm{CaCO}_{3}$ ), proving opoka applicability.

(2) Heat treatment has a significant influence on the structural properties, morphology, as well as the alkalinity of the mineral. For this reason, it is possible to direct the desired material properties depending on the needs. E.g. the alkalinity of the material can be increased easily or the porosity can be reduced. As a result of structural and chemical transformations after the thermal treatment, an improvement in the dispersion degree 
of the filler in the matrix was observed, as well as subtle differences in the mechanical properties of the composites formed (increased elongation at break).

(3) Despite the fact that the opoka rock's particle size is several times larger than that of the chalk or silica used in the study, it shows satisfactory behaviour in thermoplastic composites. Opoka composites possess similar susceptibility to deformation without breaking comparing to those filled with chalk or synthetic silica. However, secondary agglomeration of the filler indicates that it is not fully compatible with the polymer matrix due to the unfavourable physicochemical properties of the particles' surface. This indicates the necessity of chemical surface treatment, e.g., with the use of silane coupling agents. The above observations point out that, after appropriate micronisation, opoka rock may be a superior mineral filler when compared with chalk.

(4) It has been shown that the thermogravimetric method is accurate in determination of the $\mathrm{CaCO}_{3}$ content in limestone rocks. There is a great agreement of results between this technique and EDS. However, the accuracy of the TG method is higher than that of the EDS, which working principle is based on measuring the very thin layer near the surface of the sample, and not the full volume of the sample.

(5) The observed complexity and structural heterogeneity may be a significant advantage of this raw material over synthetic options. It proves that mineral materials of more complex composition than single ingredient ones (such as synthetic chalk or $\mathrm{SiO}_{2}$ ), often occurring as natural raw materials, may be effectively conditioned into proper polymer fillers upon simple physical treatment, such as micronisation and calcination.

Author Contributions: Conceptualization, R.E.P.; Methodology, R.E.P. and P.J.; Validation, M.J., T.O. and A.K.; Formal analysis, R.E.P., D.B. and B.S.; Investigation, P.M., B.S., D.B., R.K., K.D., P.J. and A.M.; Resources, R.E.P. and P.J.; Data curation, B.S., D.B., A.M. and P.M.; Writing-original draft preparation, R.E.P., P.J., D.B., B.S. and A.M.; Writing-review and editing, R.E.P., B.S., P.J., P.M., T.O. and M.J.; Visualization, B.S., P.J., A.M. and R.K.; Supervision, R.E.P. and P.J.; Project administration, R.E.P.; Funding acquisition, R.E.P. and P.J. All authors have read and agreed to the published version of the manuscript.

Funding: This research was partially supported by Ministry of Science and Higher Education (Poland).

Institutional Review Board Statement: Not applicable.

Informed Consent Statement: Not applicable.

Data Availability Statement: Not applicable.

Conflicts of Interest: The authors declare no conflict of interest.

\section{References}

1. Hubbe, M.; Gill, R.A. Fillers for Papermaking: A Review of their Properties, Usage Practices, and their Mechanistic Role. BioResources 2016, 11, 2886-2963. [CrossRef]

2. Unterweger, C.; Duchoslav, J.; Stifter, D.; Fürst, C. Characterization of carbon fiber surfaces and their impact on the mechanical properties of short carbon fiber reinforced polypropylene composites. Compos. Sci. Technol. 2015, 108, 41-47. [CrossRef]

3. John, J.; Gangadhar, S.A.; Shah, I. Flexural strength of heat-polymerized polymethyl methacrylate denture resin reinforced with glass, aramid, or nylon fibers. J. Prosthet. Dent. 2001, 86, 424-427. [CrossRef] [PubMed]

4. Mohanty, A.K.; Misra, M.; Drzal, L.T. Natural Fibers. In Biopolymers and Biocomposites, 1st ed.; CRC Press: Boca Raton, FL, USA, 2005.

5. Buasri, A.; Chaiyut, N.; Borvornchettanuwat, K.; Chantanachai, N.; Thonglor, K. Thermal and Mechanical Properties of Modified $\mathrm{CaCO}_{3}$ /PP Nanocomposites. Int. J. Civ. Environ. Eng. 2012, 6, 374-377.

6. Kahraman, M.; Kızılca, N.; Oral, M.A. Influence of mica mineral on flame retardancy and mechanical properties of intumescent flame retardant polypropylene composites. Open Chem. 2021, 19, 904-915. [CrossRef]

7. Kenig, S. Processing of Polymer Nanocomposites; Carl Hanser Verlag GmbH \& Company KG: Munich, Germany, 2019 ; p. 520.

8. Dekkers, M.E.; Heikens, D. The Effect of Interfacial Adhesion on the tensile Behavior of Polystyrene-Glass-Bead Composites. J. Appl. Polym. Sci. 1988, 28, 3809-3815. [CrossRef]

9. Fuad, M.Y.A.; Hanim, H.; Zarina, R.; Ishak, Z.A.M.; Hassan, A. Polypropylene/calcium carbonate nanocomposites-effects of processing techniques and maleated polypropylene compatibiliser. Express Polym. Lett. 2010, 4, 611-620. [CrossRef] 
10. Palutkiewicz, P.; Trzaskalska, M.; Bociaga, E. The influence of blowing agent addition, talc filler content, and injection velocity on selected properties, surface state, and structure of polypropylene injection molded parts. Cell. Polym. 2020, 39, 3-30. [CrossRef]

11. Liang, J.Z. Evaluation of dispersion of nano- $\mathrm{CaCO}_{3}$ particles in polypropylene matrix based on fractal method. Compos. Part $A$ Appl. Sci. Manuf. 2007, 38, 1502-1506. [CrossRef]

12. Sprynskyy, M. Heterogeniczność Strukturalna Oraz Właściwości Adsorpcyjne Adsorbentów Naturalnych (Klinoptylolit, Mordenit, Diatomit, Talk, Chryzotyl; Wydawnictwo Naukowe Uniwersytetu Mikołaja Kopernika: Torun, Poland, 2012.

13. Nasution, H.; Harahap, H.; Pandi, S.; Wijaya, F. Comparison of Silica and Zeolite as Fillers on Unsaturated Polyester Resin (UPR) Composites: The Effect on Tensile Properties. In Proceedings of the International Conference of Science, Technology, Engineering, Environmental and Ramification Researches (ICOSTEERR 2018)—Research in Industry 4.0, Medan, Indonesia, 30-31 August 2018; pp. 227-231.

14. Mittal, P.; Naresh, S.; Luthra, P.; Singh, A.; Dhaliwal, J.S.; Kapur, G.S. Polypropylene composites reinforced with hybrid inorganic fillers: Morphological, mechanical, and rheological properties. J. Thermoplast. Compos. Mater. 2019, 32, 848-864. [CrossRef]

15. Jakubowska, P.; Osińska-Broniarz, M.; Martyla, A.; Sztorch, B.; Sierczyńska, A.; Kopczyk, M.; Przekop, R. Thermal properties of $\mathrm{PP}-\mathrm{SiO}_{2}$ composites filled with Stöber silica. Compos. Theory Pract. 2016, 6, 161-166.

16. Cazan, C.; Enesca, A.; Andronic, L. Synergic Effect of $\mathrm{TiO}_{2}$ Filler on the Mechanical Properties of Polymer Nanocomposites. Polymers 2021, 13, 2017. [CrossRef]

17. Dobrosielska, M.; Przekop, R.E.; Sztorch, B.; Brząkalski, D.; Zgłobnicka, I.; Łępicka, M.; Dobosz, R.; Kurzydłowski, K.J. Biogenic Composite Filaments Based on Polylactide and Diatomaceous Earth for 3D Printing. Materials 2020, 13, 4632. [CrossRef]

18. Ammar, O.; Bouaziz, Y.; Haddar, N.; Mnif, N. Talc as Reinforcing Filler in Polypropylene Compounds: Effect on Morphology and Mechanical Properties. Polym. Sci. 2017, 3, 1-7.

19. Xanthos, M. Functional Fillers for Plastics, 2nd ed.; Wiley-VCH: Weinheim, Germany, 2010.

20. Rothon, R.N. Particulate Fillers for Polymers, Rapra Review Reports; Smithers Rapra Technology: Shawbury, UK, 2001.

21. Bus, A.; Karczmarczyk, A. Infrastruktura I Ekologia Terenów Wiejskich; Polska Akademia Nauk: Kraków, Poland, $2014 ;$ p. 227.

22. Brogowski, Z.; Renman, G. Characterization of Opoka as a Basis for its Use in Wastewater Treatment. Pol. J. Environ. Stud. 2004, 13, 15-20.

23. Pinińska, J. Właściwości geomechaniczne opok. Górnictwo I Geoinżynieria 2008, 32, $293-301$.

24. Marzec, M.; Pieńko, A.; Gizińska-Górna, M.; Pytka, A.; Jóźwiakowski, K.; Sosnowska, B.; Kamińska, A.; Listosz, A. The use of carbonate-silica rock (opoka) to remove iron, manganese and indicator bacteria from groundwater. J. Water Land Dev. 2017, 34, 19-204. [CrossRef]

25. Wyrwicka, K. Wykształcenie litologiczne i węglanowe surowce skalne mastrychtu lubelskiego. Biul. PIG 1977, 299, 5-98.

26. Żaba, J. Ilustrowany Stownik Skat I Minerałów; Wyd. VIDEOGRAF: Katowice, Poland, 2003.

27. Thomas, G.W. Soil pH and soil acidity. In Methods of Soil Analysis: Part 3-Chemical Methods; Bigham, J.M., Ed.; Soil Science Society of America Book Series No. 5; Soil Science Society of America and American Society of Agronomy: Madison, WI, USA, 1996; pp. 475-490.

28. Karunadasa, K.S.P.; Manoratne, C.H.; Pitawala, H.M.T.G.A.; Rajapakse, R.M.G. Thermal decomposition of calcium carbonate (calcite polymorph) as examined by in-situ high-temperature X-ray powder diffraction. J. Phys. Chem. Solids 2019, 134, 21-28. [CrossRef]

29. Curry, M.D.; Boston, P.J.; Spilde, M.N.; Baichtal, J.F.; Campbell, A.R. Cottonballs, a unique subaqeous moonmilk, and abundant subaerial moonmilk in Cataract Cave, Tongass National Forest, Alaska. Int. J. Speleol. 2009, 38, 111-128. [CrossRef]

30. Wyszomirski, P.; Szydłak, T.; Pichniarczyk, P. Charakterystyka surowcowa wybranych kruszyw mineralnych NE Polski w aspekcie trwałości betonów. Zesz. Nauk. Inst. Gospod. Surowcami Miner. I Energia Pol. Akad. Nauk. 2016, 96, 363-378.

31. Smalakys, G.; Siauciunas, R. The synthesis of $1.13 \mathrm{~nm}$ tobermorite from carbonated opoka. J. Therm. Anal. Calorim. 2018, 134, 493-502. [CrossRef]

32. RRUFF Sample Data. Available online: http:/ / rruff.info/crishttptobalite/R060648:\%2005.07.2021 (accessed on 26 June 2021).

33. RRUFF Sample Data. Available online: http:/ / rruff.info/Tridymite/R090042:\%2005.07.2021 (accessed on 26 June 2021).

34. Vichaphund, S.; Kitiwan, M.; Atong, D.; Thavorniti, P. Microwave synthesis of wollastonite powder from eggshells. J. Eur. Ceram. Soc. 2011, 13, 2435-2440. [CrossRef]

35. Zhu, L.; Sohn, H.Y. Growth of 2M-Wollastonite Polycrystals by a Partial Melting and Recrystallization Process for the Preparation of High-Aspect-Ratio Particles. J. Ceram. Sci. Technol. 2012, 3, 169-180.

36. Rodriguez-Blanco, J.D.; Shaw, S.; Benning, L.G. The kinetics and mechanisms of amorphous calcium carbonate (ACC) crystallization to calcite, via vaterite. Nanoscale 2011, 3, 265-271. [CrossRef]

37. Mroczkowska-Szerszeń, M.; Orzechowski, M. Infrared spectroscopy methods in reservoir rocks analysis-semiquantitative approach for carbonate rocks. Naft.-Gaz 2018, 11, 802-812. [CrossRef]

38. Correcher, V.; Garcia-Guinea, J.; Bustillo, M.A.; Garcia, R. Study of the thermoluminescence emission of a natural $\alpha$-crystobalite. Radiat. Eff. Defects Solids 2009, 164, 59-67. [CrossRef]

39. Wilson, J. The structure of opal-CT revisited. J. Non-Cryst. Solids 2014, 405, 68-75. [CrossRef]

40. Cheng, Y.; Liu, J.; Zhang, H.; Dai, L.; Wei, B.; Chang, Q. Increasing the hydrophobicity of filter medium particles for oily water treatment using coupling agents. Heliyon 2018, 4, e00809. 
41. Kezuka, Y.; Kawai, K.; Eguchi, K.; Tajika, M. Fabrication of Single-Crystalline Calcite Needle-Like Particles Using the AragoniteCalcite Phase Transition. Minerals 2017, 7, 133. [CrossRef]

42. Kloziński, A.; Jakubowska, P.; Przybylska, J.E.; Przekop, R. Application of Application of in-line rheological measurements for characterization of polypropylene/opoka rock powder composites. Polimery 2019, 64, 282-289. [CrossRef]

43. Teixeira, S.C.S.; Moreira, M.M.; Lima, A.P.; Santos, L.S.; Rocha, B.M.; Lima, E.S.; Costa, R.A.A.F.; Silva, A.L.N.; Rocha, M.C.G.; Coutinho, F.M.B. Composites of high density polyethylene and different grades of calcium carbonate: Mechanical, rheological, thermal, and morphological properties. J. Appl. Polym. Sci. 2006, 101, 2559-2564. [CrossRef]

44. Lazzeri, A.; Zebarjad, S.M.; Pracella, M.; Cavalier, K.; Rosa, R. Filler toughening of plastics. Part 1-The effect of surface interactions on physico-mechanical properties and rheological behaviour of ultrafine $\mathrm{CaCO}_{3} / \mathrm{HDPE}$ nanocomposites. Polymer 2005, 46, 827-844. [CrossRef]

45. Silva, A.L.N.; Rocha, M.C.G.; Moraes, M.A.R.; Valente, C.A.R.; Coutinho, F.M.B. Mechanical and rheological properties of composites based on polyolefin and mineral additives. Polym. Test. 2002, 21, 57-60. [CrossRef]

46. Zuiderduin, W.J.C.; Westzaan, C.; Huetink, J.; Gaymans, R.J. Toughening of polypropylene with calcium carbonate particles. Polymer 2003, 44, 261-275. [CrossRef]

47. Chang, H.J.; Morikawa, J.; Hashimoto, T. Thermal diffusivity of polyolefins by temperature wave analysis. J. Appl. Polym. Sci. 2006, 99, 1104-1110. [CrossRef]

48. Thio, Y.S.; Argon, A.S.; Cohen, R.E.; Weinberg, M. Toughening of isotactic polypropylene with $\mathrm{CaCO}_{3}$ particles. Polymer 2002, 43, 3661-3674. [CrossRef]

49. Dorigato, A.; D'Amato, M.; Pegoretti, A. Thermo-mechanical properties of high density polyethylene-fumed silica nanocomposites: Effect of filler surface area and treatment. J. Polym. Res. 2012, 19, 9889. [CrossRef]

50. Tomaszewska, J.; Klapiszewski, Ł.; Skórczewska, K.; Szalaty, T.J.; Jesionowski, T. Advanced organic-inorganic hybrid fillers as functional additives for poly(vinyl chloride. Polimery 2017, 62, 19-26. [CrossRef]

51. Li, K.; Ren, D.; Tang, X.; Xu, M.; Liu, X. Micro/Mesoporous $\mathrm{Fe}_{3} \mathrm{O}_{4} /$ Fe-Phthalocyanine Microspheres and Effects of Their Surface Morphology on the Crystallization and Properties of Poly(Arylene Ether Nitrile) Composites. Materials 2018, 11, 1356. [CrossRef] 